\title{
La población miliciana ante la justicia militar en Buenos Aires (1810-1823). Una comparación entre la ciudad y la campaña
}

por

Fabián Harari

Universidad de Buenos Aires / Centro de Estudios e Investigaciones en Ciencias Sociales

En Buenos Aires, luego de 1810, las guerras obligan a mantener a parte de la población masculina armada, prestando servicio en las milicias. Aun en condición de civiles, estos voluntarios gozaron del fuero especial castrense, herencia de la legislación indiana. El siguiente artículo examina la aplicación de la justicia militar para estos casos, a través del análisis de los sumarios levantados, prestando especial atención a las formas en que se sustanciaban los procesos, al uso del arbitrio judicial y a las diferencias entre la ciudad y la campaña.

Palabras Claves: justicia militar; milicias; arbitrio judicial; Buenos Aires; Derecho Indiano.

\section{INTRODUCCIÓN}

En el Río de la Plata, la transición del antiguo orden colonial a la República independiente no supuso, ya es sabido, un tránsito lineal. Las instituciones hispánicas no fueron reemplazadas inmediatamente por los mecanismos que concebía el liberalismo para gobernar la sociedad ${ }^{1}$. Entre esos dispositivos que debían ser reformados, encontramos a la justicia, que ciertamente mantuvo fuertes continuidades hasta al menos la tercera década del siglo revolucionario $^{2}$. Al estar gran parte de la población armada y prestando servicio de milicias, analizar el comportamiento de la justicia militar ante estos contingentes

${ }^{1}$ Garavaglia, 2012.

2 Candioti, 2008. 
resulta una significativa vía de acceso a la relación que debió trazar el nuevo Estado con la sociedad en la que debía intervenir.

En los últimos años, los trabajos sobre el Río de la Plata a comienzos del siglo XIX fueron sugiriendo un cuadro peculiar, en el cual el proceso revolucionario en la región habría provocado una dinámica que imbricaba, en forma compleja, cuatro desarrollos: una militarización (o «estado de guerra») de la sociedad, la aparición de las clases explotadas y subalternas como elementos de peso de las alianzas sociales y políticas (lo que se suele caracterizar como «ciclo tumultuario»), la fragmentación de la soberanía (y la expansión y jerarquización de las identidades locales) y la irrupción de la campaña como entidad política en un sistema hasta entonces signado por la centralidad de las ciudades como base del poder $^{3}$. Todo esto, montado sobre un escenario en el cual la dirección revolucionaria, concentrada en la capital, habría intentado, con énfasis variable, imponer un nuevo orden, fundamentalmente liberal y centralista ${ }^{4}$. Sobre este contexto, hay un elemento que parece estar implicado significativamente en desarrollo de estas variables: la experiencia miliciana, por la cual una importante franja de la población civil accedió al servicio de armas, sin tener que abandonar su lugar de residencia ni su actividad económica. Una experiencia que abarcó la ciudad y la campaña ${ }^{5}$.

Durante gran parte del siglo XX, la guerra ocupó un lugar central en las explicaciones históricas de la revolución. No obstante, esta variable era estudiada desde el punto de vista estrictamente castrense (o, dicho de otro modo, en términos puramente tácticos), en un relato en el que se sucedían distintas batallas que iban, respectivamente, conformando conjuntos homogénos llamados «Campaña al Alto Perú», «Campaña al Paraguay» o «Guerra del Brasil»» ${ }^{6}$. En ese contexto, el ejército representaba la voluntad no sólo estatal, sino también la nacional y, lógicamente, se estudiaban solamente las tropas de línea ${ }^{7}$. En las últimas décadas, en cambio, un análisis de la relación de ese ejército con la sociedad permitió problematizar tales supuestos. En un trabajo pionero Tulio Halperín Donghi señaló que el desarrollo de la revolución no podía explicarse por las vicisitudes de un cuerpo militar itinerante aislado de la sociedad ${ }^{8}$. Más bien, la guerra (cuyo estado puede datarse desde la primera invasión inglesa en 1806) habría producido ciertas transformaciones en la sociedad de la que

\footnotetext{
3 Fradkin, 2009a. Garavaglia, 2012.

${ }^{4}$ Idem.

${ }^{5}$ Fradkin, 2009a. Cansanello, 2003.

${ }^{6}$ Figueredo, 1960.

${ }^{7}$ Comando en Jefe del Ejército, Reseña histórica y orgánica del Ejército Argentino, 1971.

${ }^{8}$ Halperín Donghi, 1978.
} 
brotó: una militarización del conjunto de la población, la aparición de las «clases populares» y la necesidad de apelar a ellas en las disputas políticas y una «ruralización» de las bases del poder, entre las que nos interesan ${ }^{9}$. Es en ese contexto que se recupera la centralidad de las milicias en el análisis.

Sobre esas premisas, comenzaron a asomarse trabajos que intentaban comprender al ejército (o, más propiamente, «los ejércitos») desde un punto de vista social y político, analizando su composición y sus relaciones con los distintos poderes ${ }^{10}$. Lo económico, lo social y lo político no aparecen, aquí, escindido de lo militar. Algunos trabajos, como los de Juan Carlos Garavaglia, exploraron acerca de los mecanismos de financiamiento y reclutamiento ${ }^{11}$. Otros, más recientes, en particular los de Alejandro Rabinovich, aportaron novedosas hipótesis a la discusión ${ }^{12}$. En primer lugar, argumentó no estamos, en el Río de la Plata, ante un ejército nacional, sino más bien ante varios ejércitos, que adquieren una dinámica propia, no obedecen necesariamente a la lógica estatal y que contribuyeron a fragmentar el espacio político. En segundo, que no puede establecerse una tajante división entre las guerras de independencia, las civiles y la Guerra con el Brasil, sino que se trata de un continuo «estado de guerra», desde 1806 hasta 1852, en el que la economía, la política y las identidades se ven determinadas por una dinámica que se retroalimenta. En ese sentido, Raúl Fradkin llama a problematizar las nociones de profesionalización y militarización ${ }^{13}$. La primera, porque se trata de un ideal que nunca llegó a imponerse plenamente. La segunda, porque engloba procesos muy disímiles.

Esos estudios se ocupan fundamentalmente de los ejércitos de línea. Se trata de contingentes mayoritariamente forzados (sentenciados o reclutados a la fuerza), que deben abandonar (al menos momentáneamente) su hábitat y sus actividades para trasladarse al lugar del conflicto. Estos ejércitos recorrían, en ocasiones, grandes distancias y entraban en contacto con realidades diversas. Ante la falta de ayuda estatal, solían obtener recursos por su propia cuenta. Estas son las variables que otorgaban a los ejércitos una dinámica propia ${ }^{14}$. No obstante, las formaciones regulares no agotaban el sistema militar, junto a estas se desarrollaron los cuerpos milicianos, en los que la población civil, con una composición variable, prestaban servicio parcial y local ${ }^{15}$.

\footnotetext{
9 Halperín Donghi, 1972.

10 Chust y Marchena Fernández, 2007. Morrone, 1996. Bragoni, 2005. Mata, 2010.

11 Garavaglia, 2003.

12 Véase, principalmente, su tesis doctoral: Rabinovich, 2010.

${ }_{13}$ Fradkin, 2010b.

${ }^{14}$ Zimmermann, 2012.

15 Rosendi, 1900.
} 
De larga tradición hispánica, las milicias no fueron una innovación revolucionaria, sino que ostentaban una tradición colonial, más precisamente, borbónica ${ }^{16}$. En el siglo XVIII, en particular luego de la guerra de los siete años, la monarquía llevó a cabo una serie de reformas militares que implicó principalmente la creación de un ejército profesional permanente y de un sistema miliciano reglamentado. Estos ejércitos tuvieron, por primera vez, una legislación algo más sistemática y reunida en un cuerpo. Nos referimos a las Ordenanzas dictadas por Carlos III en 1768. Las milicias, por su parte, fueron una creación necesaria para suplir la insuficiencia de efectivos del Ejército de Dotación. Con el tiempo, llegaron a constituir el mayor contingente de la estructura militar en Indias. En Nueva España, las reformas llevaron a la milicia provincial de 9.200 hombres a 16.700 en la década de $1780^{17}$. A la mayoría de ellas se les da el carácter de «regladas» o «disciplinada», es decir, se les asigna una asamblea veterana encargada de su instrucción y una plana mayor veterana ${ }^{18}$. En varias partes de América las milicias adquieren son formadas por gremios artesanales o corporaciones (como los comerciantes en Nueva España) ${ }^{19}$. También se conforman con unidades de «castas»: negros libres, pardos, mulatos e indios ${ }^{20}$. Por último, existen las «urbanas» aquellas sin plana mayor veterana. También son objeto de reglamentación. En la segunda mitad del siglo estudiado, las principales cabeceras americanas reciben sus respectivos reglamentos: Cuba (1769), Venezuela (1771), Cartagena de Indias (1771 y 1778, este según el de Yucatán y Campeche), Panamá (1772), Yucatán y Campeche (1778), Perú (1793), Nueva Granada (1794) y Buenos Aires $(1801)^{21}$.

En el Río de la Plata, hasta las Invasiones Inglesas, si bien se consideraba un servicio miliciano ampliado, éste en realidad estaba más bien restringido. La separación principal se realiza de acuerdo a la existencia o no de personal veterano al frente del cuerpo. Las milicias «regladas» o «disciplinadas» contenían una asamblea veterana encargada de la instrucción y disciplina de los oficiales y la tropa. En cambio las «urbanas» no contaban con personal veterano. Existe una tercera denominación: «provinciales», que alude a las milicias que no pueden ser utilizadas fuera de las jurisdicción provincial ${ }^{22}$.

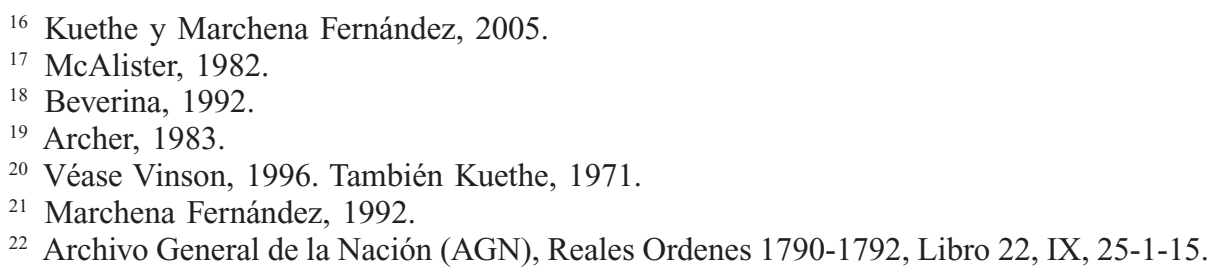


La invasión británica desata en Buenos Aires una militarización masiva unida a una politización del conjunto de la población. La novedad no sólo es su amplitud hacia amplias capas de la población, sino su carácter fundamental de «urbanas». Los oficiales son elegidos en asambleas, los cuarteles se convierten en centro de deliberación, los esclavos reciben reconocimientos ${ }^{23}$. A pesar de que se creyó que este proceso fue desde la ciudad a la campaña, nuevos estudios prueban que la segunda acompañó activamente el proceso. Luego de 1810, si bien no conserva todos los atributos de aquel comienzo (los oficiales sólo ya no serán elegidos regularmente por sus subalternos) este desarrollo no se detiene y las milicias continuaron siendo un factor importante en la ciudad y en la campaña, por lo que fueron vistas más bien con recelo por las autoridades centrales ${ }^{24}$.

Los estudios sobre las milicias en Buenos Aires han sido, ciertamente, escasos para el período independiente. Como investigación más sistemática, contamos con los trabajos de Gabriel Di Meglio. El interés de este autor está concentrado en la acción de lo que llama la "plebe urbana», donde encuentra que la experiencia miliciana se transforma en central a la hora de definir su acceso a la política, las identidades y las intervenciones. Otros trabajos, muy sugestivos, demuestran que el espíritu localista o provincial no sólo se encontraba en la campaña, sino que pueden encontrarse manifestaciones tempranas en la capital ${ }^{25}$. Esta dinámica habría de extenderse, por lo menos, hasta la aparición del rosismo ${ }^{26}$. No obstante, estudios que analizan coyunturas más tardías, encuentran problemas similares ${ }^{27}$.

Las milicias en la campaña bonaerense, en cambio, tuvieron una mayor atención por parte de los historiadores. En parte, puede deberse a su mayor visibilidad, tanto durante el período colonial, como luego de 1810: una frontera con el indio y las disputas con el artiguismo en el litoral obligaban a un estado de alerta y movilización militar de la población ${ }^{28}$. En la experiencia revolucionaria, las milicias rurales cumplieron un papel de vehiculizar la adquisición de nuevos derechos, una vía de resistencia de los sectores subalternos y la base de construcción de liderazgos locales ${ }^{29}$. Lo primero, porque el servicio permitió reclamar una condición de vecindad que se estaba ampliando hacia

\footnotetext{
23 Roberts, 1938.

24 Di Meglio, 2001.

25 Herrero, 2007.

26 Salvatore, 2003.

27 Sábato, 2008.

28 Fradkin y Ratto, 2008.

29 Fradkin, 2008.
} 
los «domiciliados» ${ }^{30}$. Lo segundo, porque con armas en la mano y en alianza con sus oficiales, podían realizar sus reclamos o exigir cierta contraprestación a cambio de apoyar los ajenos. Lo último, porque sobre la base de esas alianzas, podían erigirse reivindicaciones autonómicas sobre un Estado o una ciudad cabecera que no podía controlar el conjunto del territorio. Las milicias como elemento de acceso a la ciudadanía aparecen no sólo en los estudios sobre el Río de la Plata, sino parece ser una constante en América, e incluso en los Estados Unidos ${ }^{31}$.

Como vemos, las milicias son un objeto privilegiado para analizar la acción de las clases explotadas y subalternas ${ }^{32}$. En las últimas décadas, el estudio de la acción de estas clases ha cobrado un significativo impulso. Tanto en la ciudad como en la campaña de Buenos Aires, los estudios han enfatizado la investigación sobre lo que se dio en llamar «cultura política plebeya» o «popular», a partir de los repertorios de acción colectiva, discursos, símbolos y representaciones ${ }^{33}$. Como ya vimos, tanto en la ciudad como en la campaña, estas clases lograron efectuar una importante resistencia a los intentos reformadores de las autoridades. La hipótesis central que guía estos trabajos es que las antiguas imágenes y prácticas de antiguo régimen fueron retomadas y resignificadas por las clases subalternas en defensa de sus condiciones de vida. En la campaña, principalmente, para conservar las relaciones propias de lo que se denomina una sociedad «campesina» (acceso a la tierra, comunidad de pastos, montes y aguadas, relaciones de reciprocidad y patrocinio, favorables condiciones de venta de mano de obra), signada por normas consuetudinarias ${ }^{34}$. Una vía de acceso para examinar esa relación entre las clases subalternas y el Estado han sido, y son, los expedientes judiciales ${ }^{35}$.

En esa relación entre estas clases y el Estado, la justicia opera como un campo de observación importante ${ }^{36}$. En la medida que esta población cumple servicio miliciano, y reclama el fuero militar, resulta vital el análisis de la acción de la justicia militar sobre la población miliciana, que no se restringe

${ }^{30}$ Cansanello, 2003.

31 Jameson, 1966. London, 1951. Para la participación de población de color, véase Quarles, 1959.

${ }^{32}$ Aunque suele utilizarse el concepto de «sectores subalternos», preferimos el uso de la noción de clase, separando aquellas que entran en relaciones de explotación bajo diverso tipo (esclavos, peones, aprendices, oficiales, jornaleros) de las que, sin ser explotadas, se encuentran en una situación de subordinación social o política.

${ }^{33}$ Fradkin, 2011.

${ }^{34}$ Fradkin, 2008.

${ }^{35}$ Mallo, 2004. Fradkin, 2009b: 121-158.

${ }^{36}$ Cansanello, 2002. 
a las clases subalternas. El abordaje social e histórico de las milicias y de la justicia ha revelado que estamos ante dispositivos centrales para entender la construcción estatal en Buenos Aires ${ }^{37}$. Durante las primeras décadas que siguieron al levantamiento de mayo de 1810 , no se revelan como agentes externos a la sociedad en que se despliegan, sino que se hallan profundamente imbricados con ella y se desenvuelven en su interior. Este artículo es un intento de explorar los puntos de contacto entre la experiencia miliciana y la de la justicia en la campaña bonaerense, a través de un objeto particular: las formas que adquiere la justicia militar para el caso de los milicianos.

Hasta el momento, la justicia, como parte activa del Derecho, era considerada como un apéndice de las leyes. Los trabajos tradicionales sobre los sistemas normativos solían restringirse al estudio de la evolución legal. La ley era considerada la fuente principal (sino única) del Derecho ${ }^{38}$. Ley, en tanto norma escrita $\mathrm{y}$, de ser posible, organizada en torno a alguna codificación. Estos preconceptos no eran más que la intrapolación de los supuestos del Derecho liberal moderno a sociedades que no necesariamente habían adoptado tales fundamentos. En esos marcos, la Justicia no era sino el espacio de mejor o peor aplicación de los preceptos legales a casos concretos. El juez, un mero instrumento, la reificación de la norma ${ }^{39}$. No era, por lo tanto, sino un agente pasivo de la maquinaria estatal.

La aparición de una serie de estudios menos formales y más históricos permitió poner en duda la ecuación inmediata entre Ley y Derecho ${ }^{40}$. Ese principio liberal sólo puede ser aplicado a la sociedad que le da origen, pero habría que abstenerse de suponerlo para experiencias previas o ajenas al mundo occidental. Fuera del mundo moderno, la ley no habría tenido primacía alguna como fuente de las normas sociales: la llamada «costumbre», las nociones religiosas, la tradición, la normatividad positiva acumulada y la jurisprudencia ocupan un prominente lugar ${ }^{41}$. No existe un conjunto coherente de normas explicitadas que abarcan el universo de lo posible (para todo X, hay un Y) e intentan advertir sobre las conductas deseables - a un conjunto de individuos a los que se supone enteramente racionales, libres y responsables-antes de que estos puedan actuar (nullum crimen, nulla poena, sine lege scripta) ${ }^{42}$. Como la legislación no abarcaba el conjunto de casos posibles, en caso de conflictos,

\footnotetext{
37 Zimermann, 1998.

38 Bunge, 1930.

39 Levene 1949.

40 Tau Anzoátegui, 1982. Sánchez Bella, 1992.

41 Levaggi, 2004.

42 Beccaria, 1764.
} 
el «común actuar», concebido como jurídicamente obligatorio, podía constituir una conducta a seguir. Esa definición de «común actuar» se llenaba de contenido en las instancias de poder social concretas y todavía no reificadas, una variedad de instituciones poseen una capacidad para crear un Derecho que presenta, entre sus principales atributos, el particularismo y el casuismo ${ }^{43}$. En ese contexto, tal como indica Alejandro Agüero, la Justicia deja de ser una «Justicia de leyes» para convertirse en una «Justicia de jueces» ${ }^{44}$. Estos magistrados, en su mayoría legos, disponían, antes que de un saber jurídico, de conocimientos sobre la dinámica social y las formas de encauzarlas. Su magistratura descansa más en su poder social que en la sanción administrativa. Sus decisiones son una instancia de creación normativa. Herencia del régimen anterior, la dirección revolucionaria debe apoyarse en ellos, por lo que estos magistrados legos representan tanto la fuerza como el límite del nuevo Estado $^{45}$. A pesar de que Osvaldo Barreneche considera esas supervivencias como un obstáculo al acceso a la justicia ${ }^{46}$, Raúl Fradkin, como vimos, las considera como resistencias al avance estatal. La Justicia, así, deja de ser considerada como un simple instrumento del orden, para pasar a ser un espacio de tensión de fuerzas.

Pocos estudios se han ocupado específicamente de la justicia militar en el período independiente. El más importante de ellos es el que emprendió Ezequiel Abásolo, sobre el Derecho Penal Militar ${ }^{47}$. A pesar de su importancia, esta investigación sólo se ocupa de examinar lo que sucede en los ejércitos de línea. Con lo cual, las milicias quedan fuera del análisis. Lo que nos proponemos es empezar a examinar un problema poco abordado: cómo se desempeñaba la justicia militar para el caso de los milicianos.

En ese sentido, nuestra hipótesis de trabajo es que el fuero militar constituyó, para los milicianos de la ciudad y la campaña de Buenos Aires, una prerrogativa beneficiosa. Aunque heredera de los privilegios feudales, se extendió a población no necesariamente contemplada en el derecho castellanoindiano, por lo que las continuidades hispánicas en el funcionamiento de justicia militar redundaron en una ventaja para amplias capas de la población que prestaban servicio.

El observable que elegimos son los sumarios levantados por los tribunales militares en aquellos casos en que el acusado estuviese prestando servicio en

\footnotetext{
${ }^{43}$ Dougnac Rodrígez, 1992. Aspell, 2002.

44 Agüero, 2004.

${ }^{45}$ Candioti, 2009: 7-29.

${ }^{46}$ Barreneche, 2001.

${ }^{47}$ Abásolo, 2002.
} 
alguna milicia. Para el caso de las milicias urbanas, hemos recopilado los sumarios militares en los que el acusado es miembro del Cuerpo de Patricios (hasta 1811), de los Tercios Cívicos (hasta 1820) y de la Legión Patricia (entre 1820 y 1823$)^{48}$. Para el caso de la campaña hemos recurrido al relevamiento de las causas que involucran a miembros de los regimientos de caballería del $\mathrm{n}^{\circ} 1 \mathrm{al} \mathrm{n}^{\circ} 6$, los cuales se desempeñan en el ámbito rural. En total hemos seleccionado un observable de 146 sumarios militares, que fueron formados entre 1810 y 1823 . El recorte temporal obedece al inicio de los gobiernos revolucionarios, como fecha inicial, y a la abolición del fuero militar en 1823, como fecha de cierre del trabajo. Las causas elegidas constituyen prácticamente la totalidad de expedientes referidos a las milicias, en esos años, que se encuentran en el Archivo General de la Nación (Buenos Aires, Argentina). Hemos incorporado expedientes incompletos, pero hemos prescindido de aquellos en los que se acusaba a algún miembro del ejército regular y en el cual pudo haber intervenido un miliciano.

Las variables que guiaron el examen de los expedientes fueron: el año de inicio del proceso, la graduación y condición del acusado (veterano o voluntario), el delito por el que se acusa al sospechoso, si el delito corresponde al fuero real o personal, el derecho a la defensa, la sentencia dictada y, por último, si el mismo se conforma con arreglo a Ordenanza o disposiciones militares.

Cabe aclarar que no todas las causas cuentan con información sobre todas las variables. Por ejemplo, no en todas las causas se especifica el carácter ciudadano o veterano del acusado. En esos casos, omitimos la clasificación. Asimismo, hay varias causas que quedaron inconclusas o que fueron interrumpidas por un indulto del Poder Ejecutivo, por lo cual, no hubo ninguna sentencia firme. Por último, hay sumarios en los cuales sólo aparece la carátula en mal estado.

Durante la vigencia del Derecho Indiano, la justicia militar tuvo un carácter lego, con asesoría letrada ${ }^{49}$. Poco se modificó en este sentido luego de 1810. Formalmente, el sumario era sustanciado por un Juez Fiscal, ayudado por un secretario. El primero, un oficial veterano. El segundo, un miembro de la tropa veterano, que debía saber leer y escribir ${ }^{50}$. Según las Ordenanzas, debía

${ }^{48}$ Las milicias cívicas fueron creadas el 6 de agosto de 1811, véase Registro Oficial de la República Argentina (RORA), Buenos Aires, Imprenta Especial de Obras, 1879, t. I, p. 414. Fueron suprimidas y reemplazadas por la Legión Patricia el 6 de noviembre de 1820 , véase Archivo General de la Nación, Buenos Aires (AGN), Legión Patricia, X, 11-7-6. Hasta 1815, fue la única milicia de la ciudad y agrupaba al conjunto de la población libre. En 1815, se formó la milicia Auxiliares Argentinos, compuesta por esclavos (véase RORA, t. I: 359).

${ }^{49}$ Levaggi, 2004: 165.

${ }^{50}$ Ordenanzas, trat. VIII, tít. V, arts. $5^{\circ}, 6^{\circ}, 9^{\circ}$ y $10^{\circ}$, en Socías, 1865: 158. 
realizarse un Consejo Militar, con diferentes formalidades, ya se tratase de un oficial o un miembro de la tropa ${ }^{51}$. Sin embargo, como veremos a continuación, esto no siempre se cumplió. Muchas veces el Poder Ejecutivo suspendió la causa o decretó un indulto. Otras, la causa no pasó por Consejos Militares. No obstante, antes de abordar este problema, es indispensable realizar un breve señalamiento sobre las características del fuero militar en el Río de la Plata antes de la revolución, de modo de poder calibrar las transformaciones.

\section{El fuero militar según el Derecho Indiano en el Río de la Plata}

La denominación «fuero» remite al lugar donde se pronuncian los juicios: «jurisdicción o potestad de juzgar», según Alejandro Bacardí ${ }^{52}$. El fuero podía ser ordinario o especial. Bacardí define a este último como «reunión o agregado de los privilegios que se conceden a cierta clase de personas ${ }^{53}$ e implicaba un privilegio especial que permitía sustraer las causas a la justicia ordinaria y al individuo ser juzgado por sus pares. Dentro de los fueros especiales, existían los fueros reales o profesionales -que se circunscribían a las causas vinculadas con el ejercicio de su profesión- y los estrictamente personales, que abarcaban todos los asuntos en que estuviera implicado el titular ${ }^{54}$.

La extensión del fuero militar y la aparición de un Derecho Militar desarrollado se producen bajo la administración de la dinastía borbónica. La obra más importante de legislación militar, las Ordenanzas de 1768, promulgadas por Carlos III, resultan de un trabajo de recopilación iniciado en $1749^{55}$. La extensión del ejército y su determinante peso social en la península obligaban a una reglamentación mucho más minuciosa y sistemática. Las Ordenanzas especificaban a quiénes abarca el fuero militar:

Declaro que el referido fuero pertenece á todos los militares que actualmente sirven y en adelante sirvieren en mis tropas regladas, ó en empleos que subsistan con actual ejercicio en guerra, y que como tales militares gocen sueldo por mis tesorerías del ejército en campaña ó las provincias, comprendiéndose en esta clase los militares que se hubieren retirado del servicio y tuvieren despacho mío para gozar de fuero ${ }^{56}$.

51 Ibidem, p. 157.

52 Bacardí, 1857: 1.

${ }_{53}$ Idem.

${ }^{54}$ Levaggi, 1971: 44-91.

55 Recordemos que estas Ordenanzas van a constituir el cuerpo legal en el Río de la Plata incluso hasta la formación del Estado argentino. Serán derogadas recién en 1895 con la aprobación de un Código de Justicia Militar a nivel nacional. Véase Caballero y Zaffaroni, 1980.

${ }^{56}$ T. III, Trat. VIII, Tít. II, art. $1^{\circ}$, en Socías, 1865. 
Ello implicaba la sustracción a la justicia ordinaria, tal como reza el art. $5^{\circ}$ :

No podrán conocer de las causas civiles ni criminales de oficiales las justicias ordinarias, sino sólo el Capitán General, Consejo General o Comandante Militar del paraje donde residieren según la diferencia y circunstancia de los casos en la forma que se explicará más adelante ${ }^{57}$.

Para el caso de los milicianos, las Ordenanzas prescribían que debían someterse al fuero civil ${ }^{58}$. Esta legislación constituyó una de las fuentes del Derecho Militar en el Río de la Plata, aunque, como veremos, no la única.

Además de los textos legales, el Derecho militar castellano e indiano tenía como fuente la doctrina jurídica. En particular, el trabajo de Félix Colon de Larriategui, publicado en $1787^{59}$. Los auditores solían utilizar a este autor como autoridad a la hora de emitir dictamen ${ }^{60}$.

En el Río de la Plata, la importancia del contingente miliciano provocó la necesidad de establecer cierta reglamentación de su funcionamiento. Nos referimos al Reglamento de Milicias, de 1801. Existía, para su redacción un antecedente americano sobre este tipo de legislación: las Ordenanzas para las milicias de Cuba, de $1769^{61}$. Veamos entonces qué plantea el reglamento rioplatense con respecto al fuero militar.

En el capítulo IV, art. $1^{\circ}$, se señala que «todo soldado miliciano gozará del fuero militar» ${ }^{62}$. En el IX, se amplía la disposición a todos los oficiales y subalternos:

Todos los coroneles, oficiales, sargentos, cabos y soldados de estos cuerpos gozarán del fuero militar civil y criminal y no podrán conocer de sus causas civiles y criminales la justicia ordinaria, ni otro juez o tribunal, sino sólo el virrey capitán general y los gobernadores militares, cada uno por lo que mira a las milicias de su jurisdicción, con apelación al capitán general ${ }^{63}$.

Es decir, todo integrante de las milicias era acreedor del fuero. Nótese que, en los hechos, se estaba igualando la condición miliciana con la veterana. Esa tendencia se halla explícitamente señalada en el Cap. IV, art. $7^{\circ}$, en el que

${ }^{57}$ T. III, Trat. VIII, Tít. $1^{\circ}$, art. $5^{\circ}$, en Socías, 1865.

58 Ibidem, art. $7^{\circ}$.

59 Colon de Larriategui, 1793.

${ }^{60}$ Abásolo, 2002: 205.

${ }^{61}$ Reglamento para las Milicias de Infantería y Caballería de la Isla de Cuba, en Suárez, Gerardo Santiago, El ordenamiento militar de Indias, Academia Nacional de Historia, Caracas, 1975

${ }^{62}$ Reglamento para las Milicias Disciplinadas de Infantería y Caballería del Virreinato de Buenos Aires, Real Imprenta de Niños Expósitos, 1802, en Museo Saavedra, Manuscritos, 428.

${ }^{63}$ Ibidem, Cap. IX, art. $1^{\circ}$. 
se especifica que «los oficiales voluntarios de los cuerpos de blancos serán en todo tratados con la misma estimación que los de la tropa veterana de su clase, alternarán con ellos y gozarán plenamente de las mismas prerrogativas, excepciones y honores $\rangle^{64}$.

Esta equiparación entrañaba un conflicto ligado a la población de grupos subalternos que prestaba servicios en las milicias. Los milicianos no sólo estaban exentos de ciertos impuestos y cargas, sino que gozaban del beneficio de ser atendidos en los hospitales, siempre que estuvieran sujetos a sueldo y servicio $^{65}$. Si bien, para las penas, el Reglamento remitía a las Ordenanzas carolinas, ciertamente severas, resguardaba a los milicianos de los abusos de sus superiores ${ }^{66}$.

El Reglamento no se ocupó de distinguir entre milicias regladas y las urbanas con respecto al fuero militar. Podría deducirse que las urbanas gozarían del fuero sólo en caso de prestar servicio. Con todo, el afuero del personal miliciano provocó una serie de resistencias importantes.

Los contemporáneos advirtieron que la extensión del fuero militar a la población miliciana amenazaba con vaciar a la justicia ordinaria. En este sentido, Vértiz alertaba al ministro José Gálvez sobre el «inconveniente de que estado alistados casi todos los hombres de cada provincia, quedaría sin autoridad la jurisdicción real ordinaria, y causaría este privilegio no poca confusión en la distribución de justicia» ${ }^{67}$. En 1799, el Alcalde de 1er voto, Francisco de Escalada, se quejaba al virrey a raíz de la negativa de un oficial de milicias urbanas de pardos de comparecer ante el Cabildo. Dejaba constancia de «los perjuicios e inconvenientes que pudiera acarrear una exclusiva y separación de tantos individuos de la jurisdicción real ordinaria, y además de la que experimenta con el moderno establecimiento del Consulado» ${ }^{68}$. Evidentemente, la justicia militar abarcaba a una parte importante de la población. Es por eso que su estudio se torna significativo.

${ }^{64}$ Ibidem, Cap. IV, art. $7^{\mathrm{o}}$.

${ }^{65}$ Ibidem, art. $3^{\circ}$.

${ }^{66} \mathrm{El}$ artículo $15^{\circ}$ del Cap. III estipula: «Se prohíbe que con cualquiera pretexto puedan los cabos, sargentos y oficiales de milicias castigar con palo a los soldados. Pondrán presos a los que no cumplan con su obligación, les falten el respeto o pronta obediencia que les deben y será por los jefes del cuerpo mortificado el agresor con benignidad, pero con la debida consideración a la gravedad y circunstancias de la falta», en Reglamento para las Milicias Disciplinadas de Infantería y Caballería del Virreinato de Buenos Aires, op.cit.

${ }^{67}$ Oficio al Ministro José de Gálvez, 24 de octubre de 1780, en AGN, IX, 32-6-4, exp. 1.

${ }^{68}$ AGN, IX, 19-7-8. 


\section{La Justicia Militar Luego de 1810}

\section{Ubicación temporal}

Aquí procuraremos analizar la ubicación de las causas en el tiempo. Para ello, elaboramos el gráfico 1, donde agrupamos los expedientes según su año de inicio. En el gráfico, puede observarse la evolución de la cantidad de causas por año en la ciudad y en la campaña. Cabe aclarar que no se trata del total de delitos efectuados en la provincia, sino sólo de aquellos que fueron llevados a la justicia. Por lo tanto, si bien esta variable atiende -aunque no de manera directa- al grado de cumplimiento de las normas, representa mejor la voluntad y la posibilidad del Estado de controlar a la población miliciana.

El número total de causas en la ciudad y campaña es similar. No obstante, habría que tener en cuenta que en el espacio rural la población se encuentra más dispersa que en el urbano. Por lo tanto, las dificultades de la justicia para llevar a cabo su acción serían mayores.

Lo que se observa, para ambos casos, es una menor magnitud de causas entre 1810 y 1817, elevándose considerablemente desde 1818 hasta 1821. Las razones de esta diferencia pueden encontrarse a la particular coyuntura política y económica que afronta la provincia de Buenos Aires. Desde 1818, el Estado tiene una gran dificultad para pagar sus tropas. En 1819, esos problemas se agravan, derivando en una quiebra de las cajas estatales en $1820^{69}$. Sumado a

Gráfico 1. CANTidad de causas iniciadas sobre la población de Buenos AIRES, CIUDAD Y CAMPAÑA (1810-1823)

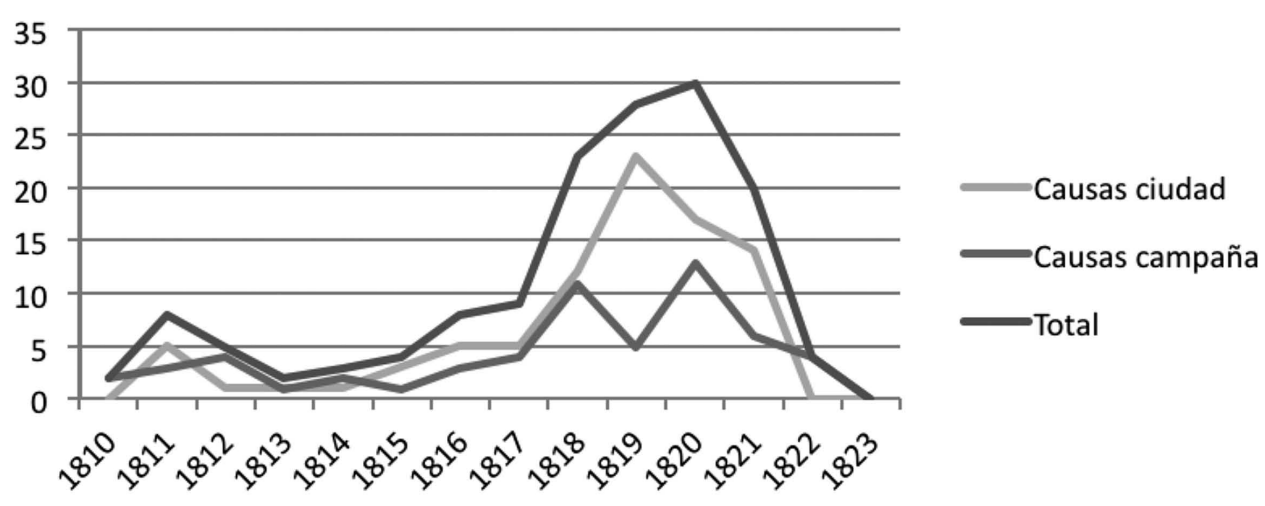

Fuente: elaboración propia sobre sumarios militares consultados en AGN.

${ }^{69}$ Halperín Donghi, 1982. 
esto, la provincia debe afrontar dos conflictos militares de peso. Desde 1818 a 1820, una guerra contra sus vecinas del litoral (Entre Ríos, Santa Fe, Banda Oriental) que culmina en la toma de la capital por las tropas santafecinas, que obliga a una serie de alistamientos resistidos por quienes deben ir a combatir ${ }^{70}$. En el transcurso de 1820, se producen dos insurrecciones militares de su propia población ${ }^{71}$. Por lo tanto, podemos sostener que en el corto período que media entre 1818 y 1821, habría habido cierta proliferación a los conflictos y una mayor tendencia al relajamiento de la disciplina militar. Encontramos en esta coyuntura cuatro sumarios que atañen a levantamientos contra la autoridad.

En la campaña, la cantidad de causas más repartida en los diferentes años que en la ciudad, puede deberse a que las problemáticas que afectan al servicio miliciano son más constantes en el espacio rural, por lo menos desde 1810 . Nos referimos a la militarización, la amenaza del indio, los conflictos con las provincias limítrofes y la escasez de recursos ${ }^{72}$.

\section{Las acusaciones}

Procuraremos, ahora, averiguar cuáles son los principales hechos por las cuales se levantan los procesos. Para ello, hemos clasificado los sumarios de acuerdo con la acusación que se realiza al reo. Esto permitirá un acercamiento a las preocupaciones de las autoridades militares y a los principales delitos.

Con respecto a esta última variable, vale la pena una aclaración. Una gran cantidad de causas acumuladas por determinado motivo no permite concluir, inmediatamente, una proporción similar de delitos o faltas. Podría darse el caso de ciertas conductas sobre las cuales los jueces militares y los oficiales no juzgasen imprescindible levantar un sumario. Con ello, tampoco se quiere afirmar lo opuesto, es decir, que ambas variables son completamente independientes. Las cifras de las acusaciones nos dicen mucho sobre cuáles eran las faltas que la justicia militar deseaba enmendar y podía llevar a juicio, toda vez que se estaba invirtiendo un esfuerzo en detener al reo y esclarecer el proceso.

Si observamos cuadro 1, vemos que el delito que más causas acarrea son aquellas que se caratulan como «heridas» y se trata de episodios en los cuales algún miliciano provoca alguna lesión a otro/s individuo/s, sea civil o militar. Semejantes acusaciones se refieren, casi siempre, a algún enfrentamiento pro-

\footnotetext{
${ }^{70}$ Fradkin y Ratto, 2008: 37-59.

${ }^{71}$ Para un análisis de esta coyuntura véase Fidel López, 1938. Levene [1933], 1972. Segreti, 1982. Halperín Donghi, 1972.

72 Mayo y Latrubesse, 1998.
} 
Cuadro 1. Cantidad de delitos

\begin{tabular}{|l|c|c|c|c|}
\hline \multicolumn{1}{|c|}{ Delitos } & $\begin{array}{c}\text { Sumarios } \\
\text { ciudad }\end{array}$ & $\begin{array}{c}\text { Sumarios } \\
\text { campaña }\end{array}$ & Totales & Porcentaje \\
\hline Heridas & 11 & 9 & 20 & 17,9 \\
\hline $\begin{array}{l}\text { Incumplimiento de deberes } \\
\text { de centinela }\end{array}$ & 18 & 1 & 19 & 17,0 \\
\hline Deserción & 3 & 10 & 13 & 11,6 \\
\hline Insubordinación & 5 & 6 & 11 & 9,8 \\
\hline Excesos & 1 & 9 & 10 & 8,9 \\
\hline Robo & 2 & 7 & 9 & 8,0 \\
\hline Conspiración/tumulto & 3 & 5 & 8 & 7,1 \\
\hline Homicidios & 3 & 4 & 7 & 6,3 \\
\hline Escándalo y destrozos & 4 & 0 & 4 & 3,6 \\
\hline Riña & 2 & 2 & 4 & 3,6 \\
\hline Golpes & 3 & 0 & 3 & 2,7 \\
\hline Secuestro & 1 & 1 & 2 & 1,8 \\
\hline Violación & 0 & 1 & 1 & 0,9 \\
\hline Estupro nefando & 0 & 1 & 1 & 0,9 \\
\hline Total & 56 & 56 & 112 & 100 \\
\hline
\end{tabular}

Fuente: elaboración propia sobre sumarios militares consultados en AGN.

vocado por cuestiones frecuentemente particulares. Algunos son producto de los roces propios del mundo castrense, que obliga a la convivencia en cuartel $\mathrm{y}$, en muchos casos, a la disputa por recursos (vestuario, armas), permisos (juego) o lugares de preponderancia. Otros, se originan en episodios de la vida civil, como pueden ser aquellos que se suceden en una pulpería a altas horas de la noche. Es lógico que estas causas lleguen a proceso, debido a que las víctimas suelen requerir atención médica y el escándalo suele expandirse, con lo que las autoridades deben tomar cartas en el asunto, aunque más no sea para realizar averiguaciones.

El segundo delito en importancia es el de incumplimiento de deberes de centinela, caratulado generalmente como «permitir fuga». La ausencia de suficientes efectivos de línea, obligaba a la justicia a recurrir adicionalmente 
a milicianos para asegurar acusados, condenados y prisioneros de guerra. En realidad, este delito fue objeto de proceso más bien en el espacio urbano que en el rural. Una de las causas de esta disparidad entre un ámbito y otro es que probablemente en la campaña el acusado tiene mayores posibilidades de eludir la justicia y, para ésta, encontrarlo es un esfuerzo mayor.

El tercer delito en importancia es la deserción; es decir, el abandono del servicio sin que medie la debida autorización. Según las investigaciones más recientes, fue el delito más importante en las tropas de línea en la región ${ }^{73}$. No obstante, en las milicias no ostenta ese peso. Aquí habría que hacer una distinción entre lo que sucede en la ciudad y en la campaña. En esta última, es el delito más importante. En cambio, en la primera, tiene un peso muy escaso. Una de las razones puede relacionarse con la diferente naturaleza del servicio. En las tropas de línea el soldado se encuentra lejos de su lugar de residencia, arriesgando su vida y bajo un régimen que puede sentir opresivo. En la campaña, si bien mantiene su vida civil, ciertas veces es obligado a trasladarse lejos de su lugar de residencia o hacer frente a peligros (invasiones indígenas, enfrentamientos con las provincias limítrofes). En la milicia de la ciudad, la tropa presta servicio en el mismo lugar donde vive, llegando incluso a dormir y comer en su casa, y no suele ser aprestado para los combates. Por lo tanto, la deserción no constituye una tentación mayor si no ha cometido ningún delito. Esta vinculación entre la deserción y la distancia con su lugar de residencia fue marcado por algunas investigaciones cuyo objeto era la tropa de línea. Allí se ponderaba la existencia de identidades locales como explicación para las deserciones ${ }^{74}$.

El cuarto delito es la insubordinación, que implica una falta de un subordinado a las órdenes de sus superiores. Generalmente, este tipo de conductas eran juzgadas y penadas en forma sumaria e inmediata por el superior a cargo, que sometía al subalterno en cuestión a algún castigo corporal o administrativo. Para que el hecho llegara a proceso judicial debía acarrear cierta gravedad, ya sea por sus consecuencias, ya sea por el grado o importancia del insubordinado en cuestión. El hecho de contar con casi una causa por año en tan vasto territorio no nos dice mucho sobre la mayor o menor disciplina imperante de los cuerpos.

Como puede apreciarse en el cuadro 1, hay dos delitos que son particularmente importantes en la campaña. El primero son los robos, que muestran una mayor preocupación de la justicia por la propiedad, teniendo en cuenta que, en este caso, abarca la posesión del ganado, la riqueza más importante de la

\footnotetext{
73 Abásolo, 2002: 200.

${ }^{74}$ Rabinovich, 2011.
} 
provincia. El segundo, más importante que el anterior, son las acusaciones por «exceso». Generalmente, se trata de imputaciones a oficiales por intromisión en la jurisdicción ordinaria o eclesiástica o por alguna conducta que pudiere perjudicar a algún particular. También se encuentra aquí casos de abuso contra los subalternos. Por ejemplo, en 1821, en la Guardia de Luján, se levantó un sumario contra el Comandante por haberle dado palos a un voluntario que se negaba a conchabarse en una chacra ${ }^{75}$. Tres de esos casos se originan por representaciones de vecinos contra el Comandante de milicias del partido, acusado de tomar reses que no le pertenecen, lo que da origen a sendos sumarios militares ${ }^{76}$. De las 9 causas, segundas en importancia, que implican «excesos de autoridad», podemos inferir la voluntad del Estado de controlar las acciones de las autoridades militares de la campaña. Tal como vimos más arriba, las milicias podían ser una base para el surgimiento de liderazgos locales, pero también eran emisarios del poder central y por lo tanto, de acuerdo al privilegio de una u otra función debían afrontar la oposición de unos u otros ${ }^{77}$.

\section{Carácter del fuero}

Corresponde aquí trazar una distinción entre los delitos llevados al fuero militar en carácter de «personal» o «privilegiado» y los que se llevan por motivos del fuero «real» o «de causa». En el primer caso, se trata de delitos que bien podrían caer bajo la jurisdicción de la justicia ordinaria, pero, bajo el privilegio jurídico, son sustraídas de esta. El segundo abarca aquellos que se relacionan con el incumplimiento de los deberes del ámbito castrense y, por lo tanto, son propios de la jurisdicción estrictamente militar ${ }^{78}$. La distinción es importante, porque permite comprender aquellas causas que, luego de 1823, pasarán al fuero común, de aquellas que continuarán bajo el dominio de la justicia militar. Si bien las Ordenanzas nada prescriben al respecto, el Reglamento de Milicias de 1801 hace una expresa diferenciación entre «los delitos puramente militares, como son las de falta de subordinación y de cumplimiento a su obligación» ${ }^{79}$ y las que se originan «no estando de servicio en campaña o guarnición ${ }^{80}$.

\footnotetext{
75 AGN, Sumarios Militares, Sala X, 30-1-2, exp. 605.

76 Ibidem, 29-10-1, exp. 116, 30-1-1. exp. 497 у 30-2-1, exp. 681.

77 Fradkin y Ratto, 2008.

78 Para profundizar en este aspecto véase Tau Anzoátegui, 1977. Levaggi, 1971: 44-91.

79 Reglamento de Milicias, op. cit, cap. X, art. 1º: 42-43.

${ }^{80}$ Ibidem: 43.
} 
En los sumarios analizados no se realiza semejante distinción. Ni los magistrados, ni los auditores, ni las autoridades se toman el trabajo de distinguir estos delitos. Incluso, en una misma causa puede hacerse alusión a una diferente tipificación del delito, revelando un insuficiente cuidado en cuanto a precisiones jurídicas se refiere. Por lo tanto, la determinación del fuero correspondiente al delito (real o personal) es una labor que debe quedar a cargo del investigador.

Tomamos como delitos del fuero personal a aquellos que no se relacionan con la actividad militar y que bien podrían haber sido juzgados por la justicia ordinaria o eclesiástica. En esta clasificación agrupamos los delitos de homicidio, robo, lesiones graves («heridas»), riña (siempre que haya sido fuera del servicio), conspiraciones políticas y delitos de lesa patria.

Para el caso del fuero real o de causa aglutinamos delitos que se refieren al incumplimiento de sus tareas militares. En las causas que encontramos, podemos señalar la deserción o el dar las voces de la misma, el incumplimiento de deberes, la desobediencia y la indisciplina.

Algunas figuras delictivas, planteadas en abstracto, no refieren al tipo de fuero. Por lo tanto, se requiere precisar el escenario y las circunstancias del hecho. Hay delitos que, de acuerdo con la legislación militar indiana, ameritan el desafuero, como los levantamientos y los tumultos ${ }^{81}$. Sin embargo, el levantamiento de enero de 1819 , la conspiración de marzo de este mismo año y la insurrección de octubre de 1820 , todos protagonizados por elementos milicianos, fueron entendidos por la justicia militar ${ }^{82}$.

${ }^{81}$ Si bien las Ordenanzas de 1768 no especifican el desafuero en caso de tumulto (véase el trat. VII, tít. II), sí lo hace Colón de Larriategui citando la Real Pragmática del 17 de abril de 1774. Véase Colón de Larriategui, 1793, t. II: 63-69.

${ }^{82}$ En enero de 1819, el tercer tercio (que nucleaba a pardos, negros y mulatos libres), se levantó contra la autoridad del Cabildo, en defensa de su condición miliciana de la ciudad y en contra de los intentos del cuerpo capitular de hacerlos marchar como ejército de línea al enfrentamiento con las fuerzas federales. En febrero de 1819, un español Miguel Olavarrieta, planea una insurrección junto con los presos por el levantamiento de enero, para el 8 de marzo. Sin embargo, el movimiento es descubierto. El 1 de octubre se produjo un movimiento popular contra el nuevo gobernador. La sublevación estaba liderada por Hilarión de la Quintana y el coronel Pagola, con el apoyo del segundo y tercer tercio cívico, los Auxiliares Argentinos y el batallón Fijo de infantería. Esa fuerza dispersó a las fuerzas de Rodríguez en la capital y forzó su huída del Fuerte hacia la campaña. Al día siguiente, el Cabildo, con la presencia de sólo cinco miembros, revocó la designación de aquel, tomó el mando y llamó a Cabildo Abierto para el 3 de octubre, en la Iglesia San Ignacio. Para los dos primeros sucesos, véase Di Meglio, 2007. Para el tercero, además del texto de Di Meglio, se recomienda López, 1938, t. IV: 463. También Beruti, 2000: 321. Y Sáenz Valiente, 1952: 177. 
Algunos delitos, planteados en abstracto, tienen cierta ambigüedad. Por ejemplo, las lesiones pueden ser consideradas un delito común o una vulneración de la necesaria disciplina militar. Por ello, realizamos una distinción entre aquellos sucesos ocurridos como consecuencia del servicio y causa del homicidio de un soldado por haber muerto a su mujer, tomada por la justicia militar, estaría siendo sustraída a la justicia ordinaria. Pero no así una riña entre dos milicianos de servicio en el cuartel. Tomemos dos casos para ejemplificar.

En 1818, el carabinero Floriano Ferreyra y el recluta trompeta Felipe Nery Resola son sorprendidos en estupro nefando ${ }^{83}$. Semejante delito puede caer en el fuero común o en el eclesiástico. No obstante, al producirse en el cuartel y durante el servicio, puede bien considerase como una falta a la disciplina y comportamiento militar y, por lo tanto, un delito del fuero real o de causa.

Tomemos otro caso: Eusebio Benencia es un soldado voluntario, cuyo oficio es peón labrador. Siendo temporada de cosecha, Benencia estaba recogiendo ganado cuando su mujer apareció ahorcada ${ }^{84}$. Es decir, estaba fuera de servicio. A pesar de ser un voluntario, de no encontrarse en actividad y acaecer el hecho en su domicilio, Benencia es llevado a la justicia militar. Tenemos aquí que, para este caso, el voluntario goza del fuero personal o privilegiado, sin ser necesariamente un militar veterano. En ese sentido, elaboramos el cuadro 2 .

Allí vemos que el 53\% de los sumarios obedecen al fuero de causa y el $43 \%$ al personal. Es decir, que en general, el fuero militar implicaba una real sustracción a la justicia ordinaria y cumplía un importante función judicial al abarcar el conjunto de la vida de los milicianos y veteranos que prestaban

Cuadro 2. Cantidad de CaUsas Según obedezcan al Fueron Personal O DE CAUSA

\begin{tabular}{|l|c|c|c|c|}
\hline \multicolumn{1}{|c|}{ Fuero } & Causas ciudad & Causas campaña & Total & Porcentaje \\
\hline Personal & 15 & 31 & 46 & 43,0 \\
\hline Causa & 28 & 29 & 57 & 53,3 \\
\hline Carácter doble & 4 & 0 & 4 & 3,7 \\
\hline Total & 47 & 60 & 107 & 100,0 \\
\hline
\end{tabular}

Fuente: elaboración propia sobre sumarios militares consultados en AGN.

\footnotetext{
${ }^{83}$ AGN, Sumarios Militares, X, 29-11-5, exp. 342.

${ }^{84}$ Ibidem, 29-10-1, exp. 123.
} 
servicio en las milicias. No obstante, vemos que en la ciudad predomina el fuero de causa. Este resultado puede comprenderse mejor si lo relacionamos con el cuadro 1 que clasifica los tipos de delito. En él, se observa en la ciudad el predomino del incumplimiento de deberes de centinela, que es claramente un delito que pertenece al fuero real o de causa. En este sentido, podemos decir que en el caso de los tercios cívicos de infantería, ha primado el peso de los sumarios militares abiertos por causas propias de la actividad militar. Sin embargo, la cuantificación omite el peso específico de cada una de las causas. En este sentido, si bien el número de causas sustraídas al fuero ordinario parece menor, aquellas que portan un peso específico mayor, las que tienen en sus manos delitos de gran envergadura política, como los tumultos y las conspiraciones, cayeron bajo el fuero militar (tumultos de 1818 , insurrección de enero de 1819, conspiración de febrero de 1819 e insurrecciones de 1820).

En la campaña, en cambio, predomina el fuero personal. Es decir, que en ese caso, el fuero militar implicaba una real sustracción a la justicia ordinaria y cumplía un importante función judicial al abarcar el conjunto de la vida de los milicianos y veteranos que prestaban servicio en las milicias.

\section{Los acusados}

La pregunta que guía este acápite es quiénes fueron los acusados y cuál era su condición. Para responder a este interrogante, se elaboró el cuadro 3. Recordemos que en algunas causas encontramos más de un miliciano procesado.

Si observamos los resultados, podemos apreciar que la mayoría de los acusados son soldados, es decir, el grado más bajo de la jerarquía castrense. Le siguen los cabos, que es el grado que le sigue inmediatamente. Si a estos dos grados le sumamos a los sargentos acusados, obtenemos que el sector subalterno (es decir, que no son oficiales) ocupa el 59,8\% de las causas, mientras que la oficialidad ocupa el otro $40,2 \%$. Si nos dejáramos guiar por este porcentaje, podríamos concluir que son los subalternos los principales responsables de las faltas y delitos o, por lo menos, de aquellas causas que son llevadas a proceso. Esta apresurada conclusión no toma en cuenta que la tropa es el componente más numeroso de cualquier cuerpo militar $\mathrm{y}$, por lo tanto, su mayor cantidad de faltas no nos dice demasiado. Para medir el peso de cada estamento en los delitos, se debe comparar la distribución porcentual de las causas con el relativo a la cantidad de efectivos que ostenta cada cargo, lo que nos permite deducir la sub o sobrerrepresentación de cada los oficiales y subalternos en los procesos. 
Cuadro 3. Cantidad de causas según el grado militar del acusado

\begin{tabular}{|l|c|c|c|c|}
\hline \multicolumn{1}{|c|}{ Cargo } & $\begin{array}{c}\text { Causas } \\
\text { ciudad }\end{array}$ & $\begin{array}{c}\text { Causas } \\
\text { Campaña }\end{array}$ & $\begin{array}{c}\text { Causas } \\
\text { totales }\end{array}$ & Porcentaje \\
\hline Soldado & 27 & 18 & 45 & 36,9 \\
\hline Cabo & 13 & 6 & 19 & 15,6 \\
\hline Capitán & 5 & 8 & 13 & 10,7 \\
\hline Comandante & 0 & 11 & 11 & 9,0 \\
\hline Teniente & 7 & 3 & 10 & 8,2 \\
\hline Sargento & 7 & 2 & 9 & 7,4 \\
\hline Subteniente & 3 & 3 & 6 & 4,9 \\
\hline Civiles & 1 & 3 & 4 & 3,3 \\
\hline Sargento Mayor & 0 & 2 & 2 & 1,6 \\
\hline Carabineros & 0 & 1 & 1 & 0,8 \\
\hline Ayudante & 1 & 0 & 1 & 0,8 \\
\hline Coronel & 0 & 1 & 1 & 0,8 \\
\hline Totales & 64 & 58 & 122 & 100,0 \\
\hline
\end{tabular}

Fuente: elaboración propia sobre sumarios militares consultados en AGN.

En este sentido, según las listas de infantería de1817, los soldados de los tercios de la ciudad suman 2.400 efectivos sobre 3.013, lo que representa el $79,65 \%{ }^{85}$. Si tenemos en cuenta que en las causas los soldados acusados representan el 36,9\% de los procesados, podemos concluir que este grado está subrepresentado en las listas de imputados. Por el contrario, los oficiales, cuya cantidad de efectivos no llega al $10 \%$, son el $23,88 \%$ de los procesados. Es decir, la oficialidad se encuentra sobrerrepresentada. En términos menos técnicos: los oficiales tienen un peso en los delitos mayor que el de su número, mientras que los soldados participan en menor proporción. Una hipótesis -difícil de constatar, pero no por ello menos plausible- es que pudieron existir delitos cometidos por voluntarios que no dieron lugar al respectivo sumario. Las distancias, los costos y las necesidades de contar con personal en servicio pudieron conspirar para que esto suceda. Obviamente, estas conclusiones deben

\footnotetext{
${ }^{85}$ AGN, Guerra-Gobierno-Hacienda 1811-1861, X, 27-7-11.
} 
matizarse toda vez que sólo encontramos la composición de los efectivos de la ciudad para 1817. No tenemos cifras para otros años.

Hay un aspecto del cuadro que es digno de señalar. En la campaña, observamos 11 sumarios instruidos contra comandantes, mientras que en la ciudad no aparece ninguno. De esos sumarios, 9 fueron levantados por excesos de autoridad, generalmente denunciados por vecinos. Los otros dos son por «escándalo», en un caso, y «tomar reses ajenas» (confiscaciones indebidas), en el otro. Esta diferencia puede deberse a que, en la campaña, los comandantes, al tener en sus manos la autoridad militar de todo un pueblo y ocuparse del cuidado de la frontera, solían ejercer funciones de policía e inmiscuirse en asuntos de la justicia ordinaria ${ }^{86}$. Asimismo, ante la falta de abastecimiento a su tropa, podían tomar recursos de los vecinos ${ }^{87}$. En definitiva, en la campaña, las relaciones entre las autoridades militares y la población era algo más problemática, ya que los límites entre una y otra quedaban desdibujados ${ }^{88}$.

Antes de pasar a una segunda variable, vale la pena realizar una aproximación a la composición social de estas milicias, para tratar de entender quiénes eran, socialmente hablando, los milicianos.

En general, hay escasos estudios que hayan realizado un análisis puntual sobre la composición de alguna milicia, con la excepción de un trabajo sobre el Cuerpo de Patricios, una milicia urbana, y para el período $1806-1810^{89}$. En ese estudio, puede observarse el predominio de los hacendados y comerciantes en la dirección y de un conjunto heterogéneo de clases subalternas (artesanos, pequeños productores) y explotadas (peones y jornaleros) en los elementos de tropa. El estudio de Herrero, también indaga, aunque muy superficialmente, sobre ciertas ocupaciones de los elementos milicianos ${ }^{90}$. Para el caso de las milicias de la campaña, Fradkin propone un esquema en el que encontramos a elementos campesinos (ya sea bajo la forma de pequeños propietarios, arrendatarios o peones) en la mayoría de las posiciones y en el cual los Comandantes parecen extraerse de elementos más ligados a las medias y grandes propiedades, aunque no exclusivamente ${ }^{91}$.

Una segunda variable que examinamos aquí se refiere al carácter veterano o voluntario de los acusados. Con las dificultades aclaradas más arriba, ob-

${ }^{86}$ Pedro Nolasco López, Comandante de Guardia del Monte, es acusado por el Alcalde de Hermandad de sustraer a la justicia ordinaria a dos reos, AGN, Sumarios Militares, X, 30-1-1, exp. 484.

${ }^{87}$ Véase AGN, Sumarios Militares, X, 30-2-1, exp. 681 y X, 30-1-1, exp. 522.

${ }^{88}$ Levaggi, 2009: 317-348.

${ }^{89}$ Harari, 2009.

${ }^{90}$ Herrero, 2007.

${ }^{91}$ Cansanello, 2002. Fradkin, 2007. 
servamos 37 casos en los que verificamos que el acusado es veterano e igual cantidad de causas que acusan a voluntarios. En el caso de la campaña, se percibe un leve predominio de los elementos veteranos.

Del mismo modo que analizamos la gravitación de los diferentes grados militares en la composición total de los acusados, aquí debemos tomar el porcentaje de acusados veteranos o voluntarios sólo resulta significativa en relación a su peso en el total del cuerpo. Para ello, tomamos la información que nos da la lista de infantería de 1817. Allí, podemos comprobar que, sobre 3.013 miembros de los tercios cívicos, sólo 144 son veteranos ${ }^{92}$. En términos porcentuales, los veteranos representan el $4,8 \%$ de la fuerza, pero el $23 \%$ de las causas en los cívicos. No tenemos cifras de la cantidad de veteranos en la campaña, pero podemos aventurar que su porcentaje con respecto a los voluntarios no debería estar muy lejos.

Sobre esto, podemos inferir que los veteranos constituían una mayor preocupación para la justicia militar que los voluntarios, quienes podían llegar a ser reclamados por la justicia ordinaria.

\section{Autoridades judiciales}

Las Ordenanzas obligaban a llevar las causas a Consejo de Guerra ${ }^{93}$. Según este cuerpo legal, un Sargento Mayor debía sustanciar el sumario, lo que implicaba caratular la causa, mandar detener al reo, llamar e interrogar a los testigos, sacar confesión al acusado y dar comunicación a las autoridades correspondientes. Para su auxilio, debía designar un escribano, como vimos. Una vez que el sumario estaba completo, debía dar una conclusión, que no podía tener carácter de sentencia definitiva ya que el sumario debía pasar al Consejo ${ }^{94}$.

En cambio, en el Reglamento de Milicias, se denomina «juez» a quien ejerce la función que las Ordenanzas daban al Sargento Mayor. A ese juez, que no era sino un oficial con grado de ayudante, se lo toma como autoridad judicial de primera instancia ${ }^{95}$. Como instancia superior no se designaba a un Consejo, sino al Capitán General (en Buenos Aires, el virrey). La sentencia

92 AGN, Guerra-Gobierno-Hacienda 1811-1861, X, 27-7-11.

${ }^{93}$ Socías, 1865, t. III: 157.

94 Ordenanzas de 1768 , trat. VIII, tít. V, arts. $5^{\circ}, 6^{\circ}, 9^{\circ}$ y $10^{\circ}$, en Ibidem: 158.

${ }^{95}$ El artículo $12^{\circ}$ del Capítulo X del Reglamento de Milicias dispone "Así en las causas de oficio, como en las de partes, se ha de ejecutar la sentencia del Capitán General, ya sea revocando o confirmando la del juez inferior.", en Reglamento de Milicias, 1801: 45. 
de primera instancia, con todo, no debía ser válida hasta que no fuera ratificada por la autoridad correspondiente. Según el artículo $5^{\circ}$ del capítulo X, debía nombrarse un «promotor fiscal», que realizase la acusación pertinente, a excepción de las causas que no eran puramente militares ${ }^{96}$.

En los sumarios examinados, quien lleva la causa es una figura que no aparece en ninguna de las reglamentaciones: el «juez fiscal». Suponemos que este cargo ocupa el lugar del sargento mayor de las Ordenanzas y la del juez en el Reglamento, quedando sin efecto el nombramiento del promotor fiscal, tal vez por falta de hombres. Sin embargo, su potestad de dictar sentencia (aun en primera instancia) no estuvo siempre clara. En algunos pasajes, utilizan «concluyo por la Patria $\rangle^{97} \mathrm{y}$ en otros «soy de parecer» ${ }^{98}$. El primero, con fuerza de sentencia; el segundo, con carácter de dictamen. Si bien no podemos ser terminantes al respecto, podemos aventurar que tal vez la poca coherencia de los cuerpos legales, la deficiente cultura jurídica y la particularidad de cada caso y de cada juez hayan influido en esta falta de criterio uniforme sobre qué función cumplía el llamado «juez fiscal».

En definitiva, estamos ante una institución judicial que no parece definir clara y explícitamente a los agentes encargados de administrarla. El juez fiscal puede aparecer como una especie de juez de instrucción, como un auditor y/o con la capacidad de dictar sentencia, según el caso. No hay adecuación a los cuerpos legales ni hay una costumbre que logre homogeneizar las prácticas de justicia.

A pesar de que la legislación así lo prescribía, pocas causas llegaban a Consejo. Podemos ver las razones en uno de los dictámenes del Auditor Miguel de Azcuénaga, en una causa en la que se acusa al capitán Gregorio Cardozo de malversar los fondos que se le dieron para los sueldos de los soldados, en la construcción de las baterías del Rosario, en 1812:

La causa será interminable si ha de juzgarse en Consejo de Guerra: los testigos que aún no se hallan ratificados se hayan distantes y dispersos, contra ellos opone el reo mil excepciones y tachas, cuya justificación sería muy morosa, padeciendo entre tanto de hecho Cardozo la prisión y más males que le resultan, a más de que todavía no ha nombrado defensor y por consiguiente la causa se halla en estado puramente sumario ${ }^{99}$.

El mismo auditor recomienda dejar el sumario en el estado incompleto como está y absolver al capitán. Como vemos, las mismas autoridades con-

\footnotetext{
96 Ibidem: 43.

${ }^{97}$ AGN, Sumarios Militares, X, 29-11-6, exp. 430, f. 41.

98 Ibidem, 29-9-8, exp. 83, f. 9.

99 Ibidem, 29,10,2, exp.187.
} 
sentían la informalidad, amparándose en las precarias condiciones y exiguos fondos para llevar adelante los procesos.

\section{El derecho a la defensa}

En el conjunto de causas examinadas, el derecho a la defensa se cumplió de forma muy desigual. Según las Ordenanzas, junto con el Consejo de Guerra, debe nombrarse defensor al acusado ${ }^{100}$. En todas las causas en las que se llegó a Consejo, el reo recibió asistencia jurídica. Sin embargo, no todas llegaron a esa instancia. Algunas recibieron sentencias emanadas del Poder Ejecutivo a partir del dictamen del Auditor o directamente del Juez Fiscal. También en estos casos la implementación del defensor fue desigual.

Por ejemplo, en 1812 , se acusa a 20 oficiales de deserción ${ }^{101}$. La causa no llegó a Consejo, pero el capitán Antonio Uriarte fue defendido por el Coronel Juan Manuel Moreno y luego por el capitán Cayetano Martínez. En cambio, la causa seguida contra el Subteniente retirado del Regimiento $\mathrm{n}^{\circ} 3$, Manuel del Río, por riña, tampoco llega a Consejo, pero el acusado no recibe defensor ${ }^{102}$.

No encontramos un patrón que pueda explicar esta irregularidad en la asistencia. No podemos atribuirla al grado del acusado o a la gravedad de la causa. Por ejemplo, en 1817, el proceso contra el soldado de milicias Miguel Lucero, acusado de faltar el respeto a su capitán en un baile, no llega a Consejo, pero el reo recibe defensor ${ }^{103}$. En cambio, ese mismo año, el Comandante de Ranchos es acusado por los vecinos de tomar reses indebidamente ${ }^{104}$. La causa no llega a Consejo, igual que la anterior, pero el acusado no recibe asistencia jurídica, si bien presenta escritos en forma personal.

En pocas causas encontramos referencias a la forma de nombramiento de los defensores. En aquellas fuentes en que puede traslucirse, observamos la misma desigualdad. En algunos casos, el defensor es nombrado por el Consejo. En otros, por los mismos acusados sobre una lista proporcionada por el juez fiscal.

En 1816, encontramos dos causas en las cuales el defensor es nombrado por el presidente de la Comisión Militar ${ }^{105}$. En uno de esos casos, el defensor

\footnotetext{
${ }^{100}$ En algunos casos, es la Comisión Militar Permanente la que toma a su cargo las tareas de Consejo de Guerra.

101 AGN, Sumarios Militares, X, 30-1-5, exp. 640.

102 Ibidem, 30-2-4, exp. 779.

103 Ibidem, 30-1-1, exp. 511.

104 Ibidem, 30-3-2, exp. 922.

105 Ibidem, 29-10-4, exp. 237 y X, 29-11-6, exp. 423.
} 
es nombrado al comienzo del proceso de instrucción ${ }^{106}$. En cambio, en 1810, ante una causa de deserción, el Juez Fiscal, luego de concluido el proceso solicita a los acusados la elección de su defensor. Tal como se consigna:

En la bajada de Santa Fe a los diez días del mes de octubre de este año el Señor Don Gabriel Meléndez, Ayudante Mayor y Juez Fiscal de esta causa pasó con asistencia de mí el escribano al cuartel donde se hallan presos los acusados de este proceso para hacerles saber se les iba a poner en consejo de Guerra y previno eligieran un oficial para que pudiera defenderlos en la presente causa; y por mí el escribano se les leyó la lista de todos los señores subalterno se les leyó la lista de todos los señores subalternos presentes de la expedición y habiéndola oído bien enterados de todo, nombraron al señor Don Juan Ezpeleta, teniente de la nona compañía del Regimiento de Caballería de la Patria y para que conste por diligencia lo firmó dicho señor... ${ }^{107}$.

El defensor, independientemente de la instancia de su nombramiento, recibía el sumario una vez sustanciado el proceso de instrucción, lo devolvía y emitía su dictamen. Es decir, se confiaba al juez fiscal y al secretario escribano, nombrado al efecto, el relevamiento de pruebas y el acusado no tenía injerencia en este procedimiento y su representante no podía interrogar a los testigos.

Sin embargo, en 1817, encontramos un caso en el que el defensor asiste a la instrucción y está presente en los interrogatorios ${ }^{108}$. Se trata de un caso de sustracción de una joven por parte del un capitán retirado, con fines amorosos. El capitán estaba casado, por lo tanto, el delito es doble. Pero el caso es que observamos, en cada interrogatorio, la presencia y la firma del defensor. Estamos, obviamente, ante una excepción.

Los defensores solían nombrarse una vez terminada la instrucción. Recibían el sumario, lo examinaban y emitían su oficio. A continuación la causa pasaba al Consejo, el que evaluaba los diferentes dictámenes, incluido el del defensor. Sin embargo, encontramos una causa donde el letrado fue nombrado al comienzo del sumario ${ }^{109} \mathrm{y}$ otra en la cual fue citado para la ratificación de los testigos ${ }^{110}$.

Podemos decir, por lo tanto, que, salvo que la causa llegara a Consejo, el derecho a la defensa se cumplía de forma muy desigual. Al no poder establecerse un patrón claro que determinara el acceso a la asistencia, evaluamos la hipótesis de que esta cuestión podía quedar al arbitrio del juez fiscal y a la amplitud de relaciones que tuviese el reo en cuestión.

\footnotetext{
106 Ibidem, 29-10-4, exp. 237, f. 2vta.

107 Ibidem, 29-11-2, exp. 292, 33vta.

108 Ibidem, 30-1-3, exp. 594.

109 Ibidem, 30-2-3, exp. 766.

110 Ibidem, 30-2-5, exp. 828.
} 


\section{Las sentencias}

Examinaremos, a continuación, la conclusión de los procesos, el tipo de penas impuestas y sus características. En primer lugar, se hace necesario realizar un relevamiento de las sentencias y su frecuencia que pueden observarse en el cuadro 4.

En dicha tabla, se observa un predominio del sobreseimiento del acusado, que se dicta en el 36,8\% de las sentencias. Luego, las incompletas, aquellas que no llegaron a sentencia, con el 22,8\%. En definitiva, en más de la mitad de los sumarios, los reos quedaron sin castigo. En tercer lugar, el destino al presidio o al ejército de línea con un 10\% de los casos. También tenemos una cantidad de casusas interrumpidas. Hay que diferenciarlas de las incompletas, ya que en las que catalogamos como «interrumpidas», la suspensión es el producto de una decisión del Poder Ejecutivo o de alguna coyuntura particular que se consigna. Luego, observamos una cierta cantidad de indultos. A diferencia de las interrupciones, aquí la causa tiene una conclusión cierta.

Podría inferirse que, a diferencia del ejército de línea, donde se practicaban penas aflictivas ${ }^{111}$, aquí estas tenían un peso menor. Es evidente que la menor

\section{Cuadro 4. Cantidad de Causas según sentencia}

\begin{tabular}{|l|c|c|c|c|}
\hline \multicolumn{1}{|c|}{ Sentencia } & Causas ciudad & Causas campaña & Total & Porcentaje \\
\hline Sobreseimiento & 23 & 19 & 42 & 39,6 \\
\hline Incompleta & 1 & 17 & 18 & 17,0 \\
\hline Servicio de línea & 10 & 2 & 12 & 11,3 \\
\hline Prisión & 8 & 2 & 10 & 9,4 \\
\hline Interrupción & 6 & 3 & 9 & 8,5 \\
\hline Indulto & 4 & 3 & 7 & 6,6 \\
\hline Pena de muerte & 2 & 1 & 3 & 2,8 \\
\hline Retiro del fuero & 1 & 1 & 2 & 1,9 \\
\hline Apercibimiento & 0 & 1 & 1 & 0,9 \\
\hline Grilletes & 1 & 0 & 1 & 0,9 \\
\hline Palos & 1 & 0 & 106 & 0,9 \\
\hline Total & 57 & 49 & 100,0 \\
\hline
\end{tabular}

Fuente: elaboración propia sobre sumarios militares examinados en AGN.

111 Nellar, 1971: 151-177. 
disciplina exigida al voluntario puede haber sido un motivo de penas menos duras. Por ejemplo, en el proceso a un soldado veterano, un cabo, un sargento y doce milicianos, por deserción en el combate de Tacuarí, el Consejo de Guerra, en su sentencia de 1811, hace una distinción entre veteranos y milicianos:

Vistas y leídas todas las informaciones, cargos y confrontaciones contra Francisco Ruiz, soldado del Regimiento de Caballería de la Patria, acusado de haber desertado de este campamento, induciendo a ello a un sargento, cabo y doce milicianos, hallándose suficientemente convencido concluyo por el Rey a que sea condenado a sufrir la pena de ser pasado por las armas, señalada por S.M. en el artículo 99, tít. 10, tratado $8^{\circ}$ de sus Reales Ordenanzas y que el cabo y doce milicianos en atención a no preceder cuando se les alista filiación, ni enterarlos de ordenanzas, ni menos consta que se les haya leído los bandos del Ejército, siendo su servicio puramente de peones sin tomar armas, que sufran la pena de cuatro años a las armas en uno de los regimientos de infantería ${ }^{112}$.

Observamos, entonces, que para el soldado de línea se impone la pena de muerte. En cambio, los milicianos sólo son condenados, por el mismo delito, a servir en el ejército. No obstante, debe recordarse que estamos examinando aquellas penas que fueron el resultado de una sentencia dictada como producto de un sumario informativo. Es decir, estamos estudiando sólo los casos llevados a autoridad judicial. No podemos dar cuenta, en este trabajo, de aquellos castigos aplicados directamente por el superior sin que mediase un proceso judicial, que pudo haber incluido castigos corporales y aflictivos.

Ahora bien, a continuación examinaremos los fallos judiciales y el uso del arbitrio judicial, que también era utilizado en la justicia militar ${ }^{113}$. Si esos fallos corresponden a Ordenanza y se basan en la rigurosidad de las pruebas, entonces, no se trata de un fuero más contemplativo ni más duro, sino de estricto cumplimiento de las normas. En relación a la cita a Ordenanzas u otros cuerpos legales, vemos que solo en 14 sobre 106 causas (en las que encontramos fundamentación) se cita a la legislación para justificar una sentencia. Ahora bien, no siempre la cita a las leyes redunda en una sentencia ajustada a las mismas. Puede darse el caso en que el magistrado procure demostrar su conocimiento en la materia, pero considere que las disposiciones legales no pueden aplicarse a ese caso, como veremos más adelante. Con todo, vemos que en la mayor parte de las sentencias no se hace mención a ese cuerpo legal. Más bien, podemos concluir que predomina el arbitrio judicial.

Para examinar el modo de utilización de esta facultad con respecto a los reos, hemos catalogamos como «benignas» aquellas sentencias que utilizasen

112 AGN, Sumarios Militares, X, 30,2,5, exp. 801, f. 19vta.

${ }^{113}$ Leiva, 1978: 93-106. 
atenuantes que morigerasen las duras penas que contemplaban las Ordenanzas. Esa clasificación dio lugar al cuadro 5. Allí observamos que el $40 \%$ de las sentencias son benignas, contra un $60 \%$ que, podría decirse, son ajustadas a las leyes (se citen o no) ${ }^{114}$.

¿Cuáles son los atenuantes que consideran los jueces militares para beneficiar al reo? En primer lugar, la ignorancia de las leyes militares. Esto queda claro porque suele preguntársele a los oficiales si a los reos, en caso de ser soldados, se les habían leído las ordenanzas y leyes militares al momento de ingresar al servicio. El juez fiscal se encargaba de preguntar «si tiene Iglesia, si le han leído las leyes penales y si ha pasado revista de comisario y hecho el servicio de sargento» ${ }^{115}$.

Otro ejemplo, más elocuente aún, es el del proceso al cabo Magallanes, en 1821. El mismo había cometido un acto de insubordinación. Uno de los vocales del tribunal colegiado explicó que, por Ordenanza, debía corresponderle la pena de muerte ${ }^{116}$. Sin embargo, se dictó una sentencia conforme al dictamen del juez fiscal, que consideraba lo siguiente:

Que aunque según lo últimamente obrado aparece que a Magallanes no se le leyeron a tiempo de filiarlo las leyes penales y juntamente no se encuentra constancia de que hubiese asistido en los pocos que se leyeron en su cuerpo, como el delito sea del modo que fuere se cometió y este por ningún título ni ordenanza debe quedar impune, concluyendo por la patria es de parecer el ministerio que a Magallanes se le debe aplicar por su ignorancia cualesquiera pena arbitraria, análoga a las circunstancias y esta puede ser el que se le destine a cualesquiera de los Regimientos de línea por el tiempo que tenga a bien este sabio consejo ${ }^{117}$.

\section{CuAdro 5. Tipo de SENTENCIA SEgúN USO DE ATENUANTES O AGRAVANTES}

\begin{tabular}{|l|c|c|c|c|}
\hline \multicolumn{1}{|c|}{ Tipo de sentencia } & Causas ciudad & Causas campaña & Total & Porcentaje \\
\hline Benigna & 27 & 20 & 47 & 40,5 \\
\hline Ajustada al proceso & 30 & 39 & 69 & 59,5 \\
\hline Perjudicial & 0 & 0 & 0 & 0,0 \\
\hline Total & 57 & 59 & 116 & 100 \\
\hline
\end{tabular}

Fuente: elaboración propia sobre la base de sumarios militares examinados en AGN.

114 Incluimos en esta categoría todas las causas que culminaron en sobreseimientos por falta de pruebas.

115 AGN, Sumarios Militares, AGN, X, 29-9-8, exp. 83, f. 5 vta.

116 Ibidem, 30-1-4, exp. 621, f. 62.

117 Ibidem, f. 61. 
Otro atenuante es haber sufrido prisión durante el proceso ${ }^{118}$. También se tenía en cuenta la conducta anterior en servicio del acusado. Se preguntaba, sobre el punto, a los testigos citados. En caso de incumplimiento de deberes de centinela, se consideraba un atenuante el hecho de que los reos hayan sido nuevamente asegurados.

En caso de desobediencia de alguna orden (como incumplimiento de deberes de centinela) oficiaba de atenuante la falta de medios con que contaba la milicia en general o el acusado en particular. El auditor de guerra, en una causa sobre fuga contra el Ayudante Mayor Marcelo Giles, en la Guardia de Luján, explica:

En vista de este sumario formado contra el ayudante Mayor don Macelo Giles comandante que fue da la Guardia de Luján por la fuga de cuatro prisioneros españoles dice: que aunque la orden de 4 del próximo pasado de f.9 se ordenó a este oficial mantuviese en competente seguridad los prisioneros que estaban a su cargo, resulta no obstante por su exposición y la del fiscal de esta causa que no hay en aquel punto proporción para ello ni guarnición suficiente para custodiarlos, resultando igualmente que luego que tuvo noticia de su fuga destacó a varias partidas para su aprehensión sin que se hubiese logrado esta, de modo que lo que se encuentra reprensible en este oficial es el no haber representado los obstáculos que encontraba para el cumplimiento de lo que se le había ordenado, pero sin complicidad alguna con los fugados, por lo que le parece al auditor que de conformidad con lo que propone el fiscal podrá VS siendo servido ordenar se sobresea en este sumario y que se ponga en libertad al oficial Giles, apercibiéndolo para lo sucesivo por la mayor exactitud en el servicio o como a VS pareciese más conforme ${ }^{119}$.

En caso de las heridas, los atenuantes son el haber sido provocado, la levedad de las heridas y restablecimiento de las mismas ${ }^{120}$. En la acusación contra Elías Lastra por haber dejado fugar un preso se tuvo en cuenta su «ancianidad» $\mathrm{y}$ «los servicios prestados en los cuerpos de línea», como un atenuante ${ }^{121}$.

Si consideramos los delitos probados y el castigo que imponían las Ordenanzas de 1768 podemos ponderar la diferencia entre una sentencia ajustada a la legislación y una basada en el arbitrio. En el caso del delito de sedición o incitación al tumulto, el art. $27^{\circ}$ del tít. X del trat. VIII prescribía la pena de muerte ${ }^{122}$. En cambio, en la causa de sedición y tumultos contra los miembros del tercer tercio cívico en enero de 1819 , sólo se aplicó la pena de vida al

\footnotetext{
118 Ibidem, 29,10,4, exp. 235, f. 10.

119 Ibidem, 29-11-6, exp. 413, f. 10.

120 Ibidem, 29-11-7, exp. 456, f. 15 y $15 v$ ta.

121 Ibidem, 30-1-1, exp. 530, f. 5.

122 Socías, 1865, t. III, p. 282.
} 
capitán Genaro González Salomón ${ }^{123}$. Para el resto hubo indultos o servicios de línea. Para los incumplimientos de deberes de centinela, el art. $56^{\circ}$ del tít. X, trat. VIII prescribía que todo centinela que abandonase su puesto sería pasado por las armas ${ }^{124}$. Por el art. $58^{\circ}$, se disponía que si se distraía podía sufrir carrera de baquetas de doscientos hombres y presidio si se quedaba dormido, y palos y dos meses de prisión si sólo se distraía en sus labores ${ }^{125}$. En los expedientes analizados, de todos los casos en que se encontró al reo culpable de incumplimiento de deberes de centinela, sólo en uno se engrilló a un individuo por seis meses en su cuartel. Según el art. $52^{\circ}$, cualquier agresor con arma de fuego o blanca, debía ser castigado con la muerte ${ }^{126}$. Este castigo tampoco se cumplió en los casos en que los acusados fueron condenados por semejante delito. Como vemos, la legislación castellano-indiana parecía demasiado rigurosa para la situación de las milicias de Buenos Aires.

Presentaremos un último caso. A nuestro juicio, el más elocuente de los analizados hasta aquí. El 16 de julio de 1809 se produjo un levantamiento criollo, en La Paz, contra las autoridades constituidas, que instauró una Junta Tuitiva ${ }^{127}$. Desde Buenos Aires, se envió una serie de regimientos voluntarios para reprimir el movimiento. Entre ellos, miembros del Cuerpo de Patricios. El Mariscal Vicente Nieto, Presidente de la Audiencia de Chuquisaca y oficial al mando de las tropas, mostró sus quejas por el comportamiento de dos oficiales del cuerpo en ocasión de la expedición. Reclamaba un Consejo de Guerra para ambos oficiales por probada insubordinación en el trayecto. Se acusaba al capitán De la Fuente de consentir el robo de ganados por parte de su tropa y haber exclamado que «todos los que venían de España eran unos pícaros, sarracenos, ladrones que venían a robar y vender esta América» ${ }^{128}$. Además, y siempre según Nieto, había advertido que «en caso que esto estuviese a favor de los indios, echaría culatas arriba y se pasaría a ellos» ${ }^{129}$.

Luego de instruido el sumario, el fiscal José Gascón, el 21 de septiembre de 1810 dictaminó:

Los acusados no pueden ni deben ser juzgados en Consejo de Guerra de oficiales generales, donde no hay grado de súplica, recurso ni apelación, de cuyos legales arbitrios no alcanza el fiscal razón alguna para privarles de ellos a los oficiales urbanos comprendidos en este proceso, sujetándolos ahora a la severidad de las

\footnotetext{
${ }^{123}$ AGN, Sumarios Militares, X, 30-3-4, exp. 957, f. 20.

124 Ibidem: 285.

${ }^{125}$ Idem.

126 Ibidem: 584.

${ }^{127}$ Para un examen de este fenómeno, puede consultarse Halperín Donghi, 1985.

${ }_{128}$ Biblioteca de Mayo, Buenos Aires, Senado de la Nación, 1961, t. XIV, p. 12451.

129 Idem.
} 
leyes militares, cuando no lo han estado estos cuerpos urbanos de nueva creación desde ella, sino con meras apariencias y accidentes efímeros de milicias regladas, ni son otra cosa propiamente que unos alistamientos de paisanos armados con uniformes arbitrarios y no el señalado por Real Orden a las urbanas de América ${ }^{130}$

El fiscal no hacía referencia a voluntarios, sino a oficiales a sueldo. Vemos en este párrafo que, a pesar de la apariencia, esas milicias no cumplían con las condiciones para ser consideradas regladas ni urbanas. Ello no quiere decir que se desconociese el cuerpo legal, ya que siempre se hace alusión a la necesidad de leérselas a los subalternos. No obstante, al parecer, los casos no parecen ajustarse demasiado a la realidad que las leyes prescriben, ya sea porque no estamos ante un ejército de línea, ya sea porque las circunstancias del armamento en Buenos Aires y la necesidad de establecer lazos con la población de menores recursos agravaban la informalidad del servicio.

\section{Algunas CONCLusiones}

Como vimos, el fuero militar supuso una continuidad con el antiguo régimen. Frente a la situación que vivía la provincia de Buenos Aires, tanto en la ciudad como en la campaña, el estado tuvo que adaptar sus mecanismos para impartir justicia. En un contexto en el cual la ley no era considerada la única fuente del derecho, la nueva coyuntura creó nuevos particularismos y, por lo tanto, nuevos marcos normativos. Antes que la fría ley, los magistrados apelaban a su sentido práctico de «hombres buenos», que permitiese el normal desarrollo de la vida militar y civil en la ciudad y la campaña. En este sentido, la justicia, en este caso, siguió siendo una «justicia de jueces», de acuerdo a una continuidad en la cultura jurisprudencial, proveniente del régimen heredado ${ }^{131}$.

En estos casos, el problema de fuero no puede circunscribirse a la sujeción a las Ordenanzas. A diferencia de la justicia moderna, determinado espacio o fuero no suponía necesariamente la aplicación de las leyes prescriptas. Un miliciano, sin ser veterano, podía ser juzgado por la justicia militar, pero no por ello sometido a las leyes. Los veteranos tampoco eran estrictamente juzgados por las Ordenanzas. Predominó, como en el Derecho Indiano, el arbitrio judicial, aunque pudo haber sido resistido por algunas autoridades castrenses. Un código como el de 1768, redactado para un ejército de línea en permanente campaña y para una coyuntura lejana en el tiempo y en el espacio, no siempre

130 Ibidem: 12444.

131 Agüero, 2005. 
se adecuaba a las necesidades de unos cuerpos mayoritariamente ciudadanos, cuyos miembros vivían en la ciudad o en los pueblos de campaña.

A pesar de estas continuidades, en ambos casos, vemos que el fuero militar constituye un beneficio para los acusados. En ningún caso se toman los agravantes para elevar la pena. En cambio, un importante porcentaje de las sentencias son benignas. El hecho de no cumplirse regularmente el derecho a la defensa no parece perjudicar particularmente a los reos. En ambos casos, ciudad y campaña, la mayoría de las sentencias culmina en un sobreseimiento. Sólo tres acusados son condenados a muerte y sólo dos son objeto de penas corporales.

Si el fuero resultaba un beneficio para la población miliciana en general, en la campaña se acentuó el beneficio para los subalternos. En primer lugar, porque se contempla un mayor porcentaje de la aplicación del fuero personal. Es decir, hay una mayor sustracción a la justicia ordinaria. En segundo, los elementos subalternos (soldados, cabos) representan un porcentaje menor de acusados con respecto a la ciudad. Es decir, en la ciudad la justicia se ocupaba particularmente de los subalternos a diferencia de la campaña. En tercero, en la campaña hay un porcentaje mucho menor de penas aflictivas. De cinco condenados a ese tipo de penas, sólo uno es de la campaña. En el espacio rural, la informalidad se acrecienta, las causas incompletas aumentan y los sobreseimientos ocupan un mayor lugar en las sentencias. A su vez, la oficialidad es más cuestionada. Esto puede deberse, a que estamos ante una sociedad en la cual el Estado posee menores recursos materiales y simbólicos para su control. En primer lugar, se trata de un espacio amplio con una frontera abierta. En segundo, el acceso a la tierra no está restringido y todavía subsisten derechos consuetudinarios sobre los recursos. En tercero, se trata de una población sumamente móvil y en dispersión. En cuarto, la pobreza demográfica y el acceso a los recursos (mucha tierra y poca gente) provocan una escasez de oferta de mano de obra que obliga a una negociación permanente con los pobladores de menores recursos. Estas características sociales, tienen su correlato lógico en el aspecto político-institucional.

Podemos concluir, entonces, que la justicia militar, para el caso de los milicianos de Buenos Aires, solía ser benigna con los acusados. El uso del arbitrio judicial y el poco apego a la legislación beneficiaban a aquellos sometidos a estos tribunales tan particulares. Es difícil aseverar, en esta instancia, si se trataba de una concesión consciente por parte de la dirigencia revolucionaria o, más bien, de la imposibilidad de ésta de ejercer un mayor control sobre el resto de las clases. Nuevas investigaciones deberían dilucidar este punto. Con todo, no podría negarse que el fuero representó una ventaja para la población que prestaba servicio y, por lo tanto, no es de extrañar que las milicias hayan 
puesto tanto empeño en oponerse a su abolición y que, de estas resistencias, hayan surgido verdaderos líderes populares, como es el caso, en Buenos Aires, de Manuel Dorrego ${ }^{132}$.

El examen de las causas judiciales en la ciudad y la campaña arroja una serie de elementos que permiten profundizar la relación entre un Estado en construcción y una población sometida a un proceso de militarización. Por un lado, la dirigencia revolucionaria intenta establecer un nuevo orden basado en el centralismo y una normativa económica y política liberal. Por el otro, una sociedad que conserva rasgos del régimen anterior pero que son defendidos como parte de la conservación de la sociedad misma. Para llevar a cabo su tarea, la primera debe acudir necesariamente a la segunda. Más aún, debe apelar a clases sociales con intereses diferentes (e incluso, en algunos casos, opuestos) a los suyos propios ${ }^{133}$. Esa apelación es armada, bajo la forma de ejércitos de línea o milicia. En ese contexto, la construcción de un nuevo orden no puede ser lineal ni abierto, sino que debe intentar su inserción por las vías tradicionales. Como vemos, hasta 1823, los milicianos gozan de un fuero especial, que puede ser considerado como un resabio estamental, desde una óptica liberal o como una prerrogativa de las clases subalternas, desde una más realista.

\section{BIBLIOGRAFÍA}

Abásolo, Ezequiel, El derecho penal militar en la historia argentina, Buenos Aires, Advocatus, 2002.

Agüero, Alejandro, "Clemencia, perdón y disimulo en la justicia criminal del Antiguo Régimen. Su praxis en Córdoba del Tucumán, siglos XVII y XVIII”, Revista de Historia del Derecho, 32 (Buenos Aires, 2004): 33-81.

Agüero, Alejandro, "Formas de continuidad del orden jurídico. Algunas reflexiones a partir de la justicia criminal de Córdoba (Argentina), primera mitad del siglo XIX”, Nuevo Mundo Mundos Nuevos, [En línea] Debates, EHESS (París, 2010), Disponible en: http://nuevomundo.revues.org/59352 (Verificada el 5/6/2015).

Agüero, Alejandro, "Formas de continuidad del orden jurídico. Algunas reflexiones a partir de la justicia criminal de Córdoba (Argentina), primera mitad del siglo XIX",

132 Manuel Dorrego se constituyó como un líder popular, centralmente, con base en la población de la campaña. En 1823, se opuso a la refirma liberal que acarreaba la abolición del fuero militar, en particular, para los milicianos. El descontento con esta reforma provocó un levantamiento llamado Motón de Tagle. Véase Di Meglio, 2006. Díaz, 1952: 18-33.

133 Rosanvallón, Pierre, La sociedad de los iguales, Barcelona, RBA libros, 2012. 
Nuevo Mundo Mundos Nuevos, Debates, 2010. Disponible en: http://nuevomundo. revues.org/59352. (Verificada el 5/6/2015).

Agüero, Alejandro, Ciudad y poder político en el Antiguo Régimen. La tradición castellana, Córdoba, Cuadernos de Historia, 2005.

Archer, Christon, El Ejército en el México Borbónico, 1760-1810, México, FCE, 1983.

Aspell, Marcela, "Los factores de distorsión de los mecanismos del control social de la población rural en la jurisdicción de Córdoba del Tucumán", Revista de historia del Derecho, 30 (Buenos Aires, 2002): 87-147.

Bacardí, Alejandro de, Nuevo Colon: o sea Tratado de derecho militar de España y sus indias, Barcelona, Establecimiento Tipográfico de Narciso Ramírez, 1857.

Barreneche, Osvaldo, Dentro de la ley, TODO. La justicia criminal de Buenos Aires en la etapa formativa del sistema penal moderno de la Argentina, La Plata, Ediciones Al Margen y Universidad Nacional de La Plata, 2001.

Barriera, Darío, "Justicias, jueces y culturas jurídicas en el siglo XIX rioplatense", Nuevo Mundo Mundos Nuevos [En línea], Debates, 2010, Puesto en línea el 23 marzo 2010. URL: http://nuevomundo.revues.org/59252. (Verificada el 5/6/2015).

Beccaria, Marqués de, [1764], De los delitos y las penas, Madrid, Aguilar, 1969.

Beruti, Juan Manuel: Memorias curiosas, Buenos Aires, Emecé, 2000.

Best, Félix, Historia de las guerras argentinas, Buenos Aires, Péuser, 1960, 2 tomos.

Beverina, Juan, El Virreinato de las Provincias del Río de la Plata. Su organización militar, Buenos Aires, Círculo Militar, 1992.

Bragoni, Beatriz, "Guerreros virtuosos, soldados a sueldo. Móviles de reclutamiento militar durante el desarrollo de la guerra de independencia”, Dimensión Antropológica, 12 (México, 2005): 19-53.

Bunge, Carlos Historia del Derecho Argentino [1913], Buenos Aires, Espasa Calpe, 1930.

Candioti, Magdalena (2008), "Fueros, jueces y jurados: el debate público en torno a la reforma judicial rivadaviana", Papeles de trabajo. Revista electrónica del Instituto de Altos Estudios Sociales de la Universidad Nacional de General San Martín, 2/3 (San Martín, 2008).

Candioti, Magdalena, "Historia y cuestión criminal. Notas sobre el despliegue de una curiosidad", Marco Sozzo (comp.), Historias de la cuestión criminal en la Argentina, Buenos Aires, Del Puerto, 2010: 7-29.

Cansanello, Oreste Carlos De súbditos a ciudadanos. Ensayo sobre las libertades en los orígenes republicanos. Buenos Aires 1810-1852, Buenos Aires, Ediciones Imago Mundi, 2003. 
Cansanello, Oreste Carlos, "Justicias y penas en Buenos Aires. De los bandos de buen gobierno a la Constitución Nacional”, Sandra Gayol y Gabriel Kessler, Violencias delitos y justicias en la Argentina, Manantial, Buenos Aires, 2002, pp. 125-140.

Cansanello, Oreste Carlos, De súbditos a ciudadanos. Ensayo sobre las libertades en los orígenes republicanos. Buenos Aires 1810-1852, Buenos Aires, Ediciones Imago Mundi, 2003.

Cavallero, Ricardo y Zaffaroni, Eugenio, Derecho penal militar: lineamientos de la parte general, Buenos Aires, Ariel, 1980.

Chust, Manuel y Marchena Fernández, Juan (eds.), Las armas de la nación. Independencia y ciudadanía en Hispanoamérica (1750-1850), Madrid, Iberoamericana, 2007.

Colón de Larriatregui, Félix, Juzgados Militares para España y sus Indias, Madrid, Imprenta de Viuda de Ibarra, 1788.

Comando en Jefe del Ejército, Reseña histórica y orgánica del Ejército Argentino, Buenos Aires, Círculo Militar, 1971, 3 tomos.

Di Meglio, Gabriel (2001), "Un nuevo actor para un nuevo escenario. La participación política de la plebe urbana de Buenos Aires en la década de la revolución (1810-1820)", Boletín del Instituto de Historia Argentina y Americana "Dr. Emilio Ravignani”, $3 / 24$ (Buenos Aires, $2^{\circ}$ semestre de 2001): 7-43.

Di Meglio, Gabriel, ¡Viva el bajo pueblo! La plebe urbana de Buenos Aires y la política entre la Revolución de Mayo y el rosismo, Buenos Aires, Prometeo, 2006.

Díaz, Benito, "La igualdad ante la ley: abolición de los fueron personales (18221823)", Trabajos y Comunicaciones, 3 (La Plata, 1952): 18-33.

Dougnac Rodríguez., Alberto, Manual de Historia del Derecho Indiano, México, Universidad Autónoma de México, 1994

Figueredo, Juan, Historia Militar de los regimientos argentinos, Buenos Aires, Gráficas Modernas, 1945.

Fradkin, Raúl y Ratto, Silvia, “Territorios en disputa. Liderazgos locales en la frontera entre Buenos Aires y Santa Fe", Raúl Fradkin y Jorge Gelman, (comp.), Desafios al Orden. Politica y sociedades rurales durante la Revolución de Independencia, Rosario, Prohistoria, 2008: 37-59.

Fradkin, Raúl, "Cultura política y acción colectiva en Buenos Aires (1806-1829): un ejercicio de exploración", Raúl Fradkin (ed.), ¿Y el pueblo dónde está? Contribuciones para una historia popular de la revolución de independencia en el Río de la Plata, Prometeo, Buenos Aires, 2008: 27-66.

Fradkin, Raúl, "Ley, costumbre y relaciones sociales en la campaña bonaerense (siglos XVIII-XIX)", R. Fradkin, (comp.), La ley es tela de araña. Ley, justicia y sociedad rural en Buenos Aires, 1780-1830, Buenos Aires, Prometeo, 2009a: 121-158. 
Fradkin, Raúl, “Tradiciones militares coloniales. El Río de la Plata antes de la revolución”, Flavio Heinz (comp.), Experiências nacionais, temas transversais: subsídios para uma história comparada da América Latina, São Leopoldo, Editora Oikos, 2009b, pp. 74-126.

Fradkin Raúl, "La acción colectiva popular en los siglos XVIII y XIX: modalidades, experiencias, tradiciones", Nuevo Mundo Mundos Nuevos [En línea], Debates, Puesto en línea el 18 junio 2010a, consultado el 07 febrero 2012. URL: http:// nuevomundo.revues.org/59749 (Verificada el 5/6/2015).

Fradkin, Raúl, "La revolución en los pueblos del litoral rioplatense", Estudos IberoAmericanos, 36/2 (2010b): 242-265.

Fradkin, Raúl, "Los actores de la revolución y el orden social", Boletín del Instituto de Historia Argentina y Americana Dr. Emilio Ravignani, 33 (Buenos Aires, 2011): 79-90. Disponible en: http://www.scielo.org.ar/scielo.php?script=sci_ arttext\&pid=S0524-97672011000100013\&lng=es\&nrm=iso>. ISSN 0524-9767. (Verificada el 5/6/2015).

Garavaglia, Juan Carlos, "Derecho y poder político: algunas reflexiones a la luz de la experiencia rioplatense", Carolina Piazzi, (comp.), Modos de hacer justicia. Agentes, normas y prácticas, Rosario, Prohistoria, 2012, pp. 13-24.

Garavaglia, Juan Carlos, "Ejército y milicia: los campesinos bonaerenses y el peso de las exigencias militares, 1810-1860”, Anuario IHES, 18 (Tandil, 2003):123-152.

Garavaglia, Juan Carlos, "Ejército y milicia: los campesinos bonaerenses y el peso de las exigencias militares, 1810-1860”, Anuario IHES, 18 (Tandil, 2003): 153-187.

Garavaglia, Juan Carlos, "La justicia rural en Buenos Aires durante la primera mitad del siglo XIX (estructuras, funciones y poderes locales)", Poder conflicto y relaciones sociales. El Río de la Plata, XVIII-XIX, Rosario, Homo Sapiens, 1999: 89-121.

Halperín Donghi, Tulio, "Militarización revolucionaria en Buenos Aires, 1806-1815", Tulio Halperín Donghi (comp.): El ocaso del orden colonial en Hispanoamérica, Buenos Aires, Sudamericana, 1978: 121-158.

Halperín Donghi, Tulio, Guerra y finanzas en los orígenes del Estado argentino (1791-1850), Buenos Aires, Editorial Belgrano, 1982.

Halperín Donghi, Tulio, Revolución y guerra. Formación de una elite dirigente en la Argentina criolla, Buenos Aires, Siglo XXI, 1972.

Herrero, Fabián, Movimientos de pueblo. La política en Buenos Aires luego de 1810, Buenos Aires, Ediciones Cooperativas, 2007.

Jameson, Hugh, "Subsistence for Middle Status Militia, 1776-1781", Military Affairs, 30/3 (otoño-invierno de 1966): 121-134.

Johnson, Lyman, The problem of order in changing societies. Essays on crime and policing in Argentina and Uruguay, Albuquerque, University of New Mexico Press, 1990. 
Kuethe, Allan y Marchena, Juan (eds.), Soldados del Rey. El ejército borbónico en América colonial en vísperas de la Independencia, Castellón de la Plana, Universitat Jaume I, 2005.

Kuethe, Allan, "The Status of Free Pardo in the Disciplined Militia of New Granada", The Journal of Negro History, 56/ 2 (Washington, April 1971): 105-117.

Leiva, Alberto, "La institución del arbitrio judicial en el Río de la Plata durante el período 1785-1810", Revista de Historia del Derecho, 24 (Buenos Aires, 1978): 93-106.

Levaggi, Abelardo (2004), Manual de Historia del Derecho Argentino, Buenos Aires, Lexis Nexis, 2004, t. I.

Levaggi, Abelardo, "Las penas de muerte y aflicción en el Derecho Indiano rioplatense (primera parte)", Revista Historia del Derecho, 3 (Buenos Aires, 1975): 81-164.

Levaggi, Abelardo, "Díptico de Historia del Fuero Militar", Revista de Historia del Derecho "Ricardo Levene”, 28 (Buenos Aires, 1991): 81-129.

Levaggi, Abelardo, "La alcaldía de Hermandad en el Virreinato del Río de la Plata (1776-1810)", Revista de Estudios Histórico-Jurídicos, 31 (Valparaíso, 2009): 317-348.

Levaggi, Abelardo, "Los fueros especiales. Contribución al estudio de la administración de justicia en el Río de la Plata", Revista del Instituto de Historia del Derecho "Ricardo Levene”, 22 (Buenos Aires, 1971): 44-91.

Levaggi, Abelardo, Manual de Historia del Derecho Argentino, Buenos Aires, Lexis Nexis, 2004.

Levene, Ricardo, Historia del derecho argentino: historia de las instituciones del derecho público y privado indiano, Buenos Aires, Kraft, 1946.

Levene, Ricardo, La anarquía de 1820 y la iniciación de la vida política de Rosas, [1933] en Obras Completas, t. IV, Buenos Aires, Academia Nacional de la Historia, 1972.

London, Lena, “The Militia Fine 1830-1860”, Military Affairs, 15/3 (Autumn, Otoño de 1951): 133-144.

López, Vicente Fidel, Historia de la República Argentina, t. IV, Buenos Aires, Lectum, 1938.

Mallo, Silvia, La sociedad rioplatense ante la justicia: 1750-1850, La Plata, Archivo Histórico de la Provincia de Buenos Aires, 2004.

Marchena Fernández, Juan, Ejército y milicias en el mundo colonial americano, Madrid, Mapfre, 1992.

Mata, Sara, "Movilización rural y liderazgos. Salta en la guerra de independencia", Revista digital de la Escuela de Historia, 2/3 (Rosario, 2010): 7-24. 
Mayo, Carlos y Latrubesse, Amalia, Terratenientes, soldados y cautivos. La frontera, 1736-1815, Buenos Aires, Editorial Biblos. 1998.

McAlister, Lyle, El fuero militar en Nueva España, México, UNAM, 1982.

Meli, Rosa, Los fueros militares en el derecho indiano, Caracas, Academia Nacional de la Historia, 1979.

Morrone, Francisco (1996), Los negros en el ejército: declinación demográfica y disolución, Buenos Aires, Centro Editor de América Latina, 1996.

Nellar, Fued, "Aplicación de medidas disciplinarias y de penas por faltas y delitos cometidos en el Ejército de la Revolución de Mayo, años 1811 a 1816", Boletín Informativo, I/6-7 (Buenos Aires, 1971): 151-177.

Pérez Garzón, Juan Sisino y Espadas Burgos, Manuel, Milicia nacional y revolución burguesa: el prototipo madrileño, 1808-1874, Madrid, CSIC, 1978.

Quarles, Benjamin, “The Colonial Militia and Negro Manpower", Mississippi Valley Historical Review, 45/4 (Mississippi, marzo 1959): 643-652.

Rabinovich, Alejandro, "El fenómeno de la deserción en las guerras de la revolución e independencia del Río de la Plata: 1810-1829”, E.I.A.L., 22/1 (Tel Aviv, 2011): 33-56.

Rabinovich, Alejandro, "La société guerrière. Pratiques, discours et valeurs militaires au Rio De La Plata, 1806-1852", Tesis de Doctorado, EHESS, París, 2010.

Roberts, Carlos, Las Invasiones Inglesas del Río de la Plata, Buenos Aires, Emecé, 1938.

Rosanvallón, Pierre, La sociedad de los iguales, Barcelona, RBA libros, 2012.

Rosendi, José, "Dos conceptos, lo militar y lo miliciano", Revista Nacional, XXXII, (Buenos Aires, 1900).

Sábato, Hilda, Buenos Aires en armas. La revolución de 1880, Buenos Aires, Siglo XXI, 2008.

Sáenz Valiente, José María, Bajo la campana del Cabildo, Buenos Aires, Kraft, 1952.

Salvatore, Ricardo, Wandering Paysanos. State Order and Subaltern Experience in Buenos Aires During the Rosas Era, Durham and London, Duke University Press, 2003.

Sánchez Bella, Ismael, De la Hera, Alberto \& Díaz, Rementería, Carlos (1992) Historia del Derecho Indiano, Madrid, Mapfre, 1992.

Sánchez Bella, Ismael, De la Hera, Alberto y Díaz, Rementería, Carlos, Historia del Derecho Indiano, Madrid, Mapfre, 1992.

Santoni, Pedro, "A fear of the People: The Civic Militia of Mexico in 1845", The Hispanic American Historical Review, LXVIII/2 (North Carolina, 1988): 269-288. 
Segreti, Carlos, El país disuelto 1820/1821, Buenos Aires, Editorial Belgrano, 1982.

Socías, Mariano, Ordenanzas de Su Majestad para el régimen, disciplina subordinación y servicio de sus Ejércitos, Madrid, Escuela Tipográfica de Madrid, 1865.

Tau Anzoátegui, Víctor, Casuismo y sistema. Indagación histórica sobre el espíritu del Derecho Indiano, Buenos Aires, Abeledo-Perrot, 1992.

Tau Anzoátegui, Víctor, Casuismo y sistema. Indagación histórica sobre el espíritu del Derecho Indiano, Buenos Aires, Abeledo-Perrot, 1992.

Vinson, Ben III, “Las compañías milicianas de pardos y morenos en la Nueva España. Un aporte para su estudio", Carmen Blázquez, Carlos Contreras y Sonia Pérez (coords.), Población y estructura urbana en México, siglos XVIII y XIX, Xalapa, Instituto Mora-Universidad Veracruzana-UAM, 1996: 239-250.

Zimermann, Eduardo, Judicial Institutions in Nineteenth-Century Latin American, Londres, Institute for Latin American Studies, 1998.

Zimermann, Eduardo, "Guerra, fuerzas militares y construcción estatal en el Río de la Plata, siglo XIX. Un comentario", Juan Carlos Garavaglia, Juan Pro Ruiz y Eduardo Zimmermann (eds.), Las fuerzas de guerra en la construcción del Estado. América Latina, siglo XIX, Rosario, Prohistoria, 2012, pp. 185-204.

Fecha de recepción: 1 de febrero de 2013.

Fecha de aceptación: 25 de octubre de 2013.

\section{Militiamen brought to military justice in Buenos Aires (1810- 1823). A comparison between town and countryside}

After the Revolution, ongoing wars required part of the male population of Buenos Aires to remain armed and serve in the militias. Although they had civilian status, these militiamen benefitted from a special military jurisdiction, inherited from the Laws of the Indies. The following article examines the application of military justice in these cases, using research based on an analysis of legal proceedings, paying particular attention to the ways in which the cases are substantiated, the use of judicial discretion and the differences between town and countryside.

KeY words: Military justice; militias; judicial discretion; Buenos Aires; Colonial Laws. 